\title{
Oceans and Society: Feedbacks between ocean and human health
}

\author{
Kirsty L Nash ${ }^{1,2,3}$, Ingrid Van Putten ${ }^{2,4}$, Karen Alexander ${ }^{2,4}$, Christopher Cvitanovic ${ }^{2,5}$, \\ Silvana Bettiol ${ }^{6}$, Jeff Dambacher ${ }^{2,3}$, Anna K Farmery ${ }^{2,7}$, Emily J Flies ${ }^{8}$, Sierra Ison ${ }^{2,3}$, \\ Rachel Kelly ${ }^{2,3}$, Mary Mackay ${ }^{2,4}$, Linda Murray ${ }^{9}$, Kimberley Norris ${ }^{10}$, Lucy M \\ Robinson ${ }^{11,12,13}$, Jennifer Scott ${ }^{10}$, Delphi Ward ${ }^{3}$, and Joanna Vince ${ }^{2,14}$ \\ ${ }^{1}$ Future Seas \\ ${ }^{2}$ Centre for Marine Socioecology \\ ${ }^{3}$ Institute for Marine and Antarctic Studies, University of Tasmania \\ ${ }^{4}$ CSIRO, Oceans and Atmosphere \\ ${ }^{5}$ Australian National Centre for the Public Awareness of Science, Australian National \\ University \\ ${ }^{6}$ School of Medicine, College of Health and Medicine, University of Tasmania \\ ${ }^{7}$ Australian National Centre for Ocean Resources and Security, University of Wollongong \\ ${ }^{8}$ School of Natural Sciences, University of Tasmania \\ ${ }^{9}$ School of Health Sciences, College of Health, Massey University \\ ${ }^{10}$ School of Psychological Sciences, University of Tasmania \\ ${ }^{11}$ Oceans Institute, The University of Western Australia \\ ${ }^{12}$ Oceans Graduate School, The University of Western Australia \\ ${ }^{13}$ CSIRO Oceans and Atmosphere \\ ${ }^{14}$ School of Social Sciences, University of Tasmania
}

October 2, 2020

\begin{abstract}
The concentration of human population along coastlines has far-reaching effects on ocean and societal health. The oceans provide benefits to humans such as food, coastal protection and improved mental well-being, but can also impact negatively via natural disasters. At the same time, humans influence ocean health, for example, via coastal development or through environmental stewardship. Given the strong feedbacks between ocean and human health there is a need to promote desirable interactions, while minimising undesirable interactions. To this end, we articulate two scenarios for 2030. First, Business-asUsual, named 'Command \& (Out of) Control', focuses on the anticipated future based on our current trajectory. Second, a more sustainable scenario called 'Living $\&$ Connecting', emphasises the development of interactions between oceans and society consistent with achieving the Sustainable Development Goals. We describe a potential pathway to achieving the 'Living \& Connecting' scenario, centred on improving marine citizenship, achieving a more equitable distribution of power among stakeholders, and more equitable access to resources and opportunities. The constituent actions of this pathway can be categorised into four groups: (i) improved approaches to science and health communication that account for society's diverse values, beliefs and worldviews, (ii) a shift towards more trusted relationships among stakeholders to enable two-way knowledge exchange, (iii) economic incentives that encourage behavioural changes necessary for achieving desired sustainability outcomes, and (iv) stronger regulations that simultaneously focus on ocean and human health. We contend that these changes will provide improved outcomes for both oceans and society over the UN Decade of Ocean Science.
\end{abstract}

https://doi.org/10.1007/s11160-021-09669-5 
This paper is part of the Future Seas project www.futureseas2030.org, and has been submitted to the Future Seas special issue in Reviews in Fish Biology 8 Fisheries to be published in 2021.

\section{Graphical Abstract}

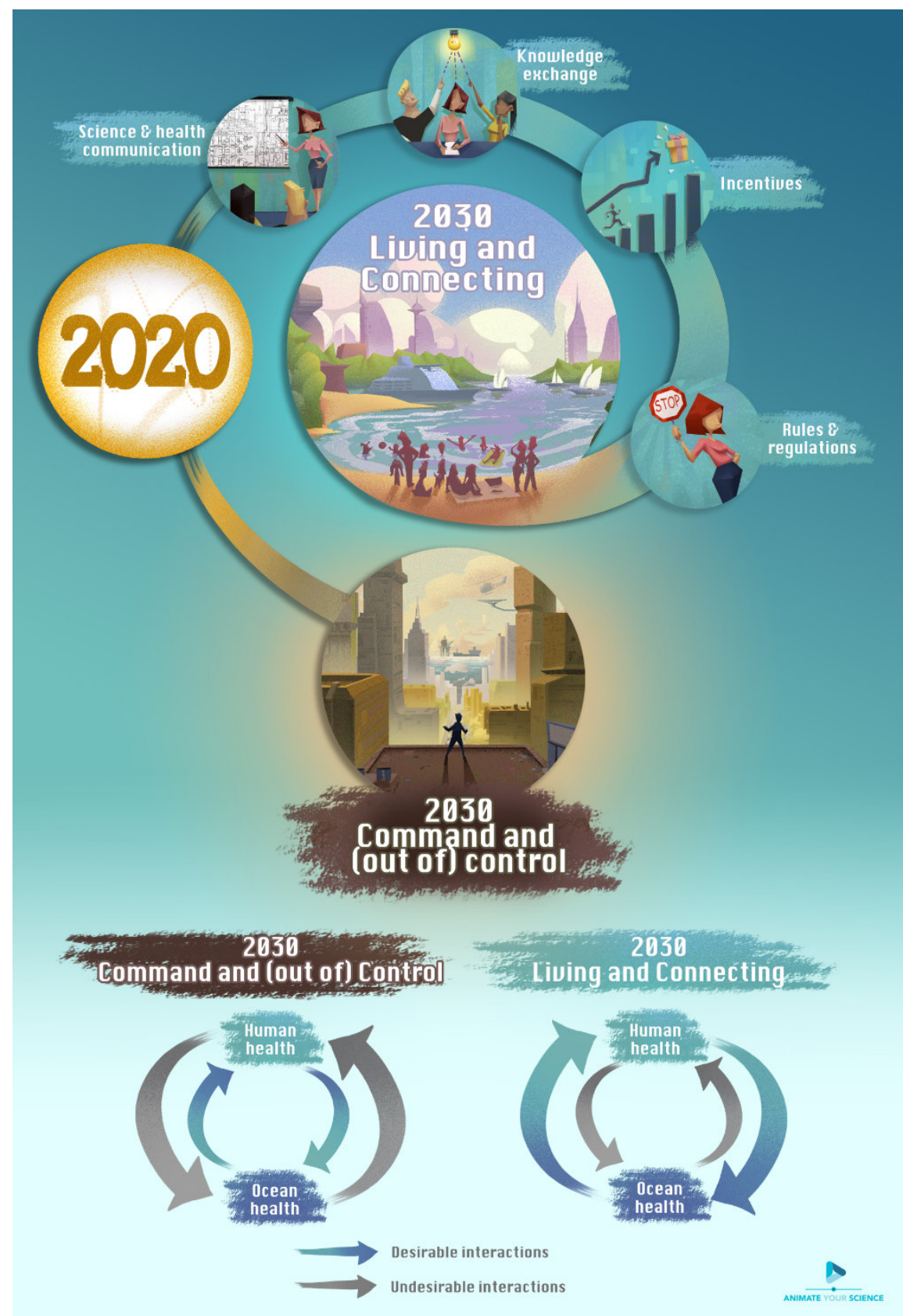

Keywords: power and agency, human development, human health, well-being, sense of place, food system 


\section{Introduction}

Over $40 \%$ of the global population and most of the world's megacities are located in coastal areas (Neumann et al. 2015; Seto 2011), with migration towards urban coastal areas expected to continue beyond 2030 (Merkens et al. 2016; Steffen et al. 2015). The co-location of human population centres at the interface between land and sea has far-reaching effects on the health of our oceans and the health of society (Figure 1; Box 1). Human health is dependent on the ocean because many coastal communities depend on the marine environment for food, shelter, livelihoods, spiritual wellbeing, medicines and other resources (Fleming et al. 2019; Malve 2016). Proximity to coastal areas has also been associated with better quality of life, and enhanced mental health and well-being (Britton et al. 2018; Garrett et al. 2019), due to reductions in stress, improved air quality, relaxation and physically active lifestyles, increased social interactions, and spiritual connection to the ocean (Fleming et al. 2019). At the same time, coastal communities also face ocean-associated risks and are vulnerable to natural disasters such as storm surges (Arkema et al. 2013; Neumann et al. 2015). These desirable and undesirable interactions between society and the oceans affect human health; for example, ocean animals and plants provide essential nutrition for humanity, while oceanic plankton supports oxygen production into our atmosphere. Just as the oceans influence human health, society impacts ocean health, through coastal development, pollution, and industry-driven ecosystem degradation (Halpern et al. 2017). In contrast, close cultural connection with the oceans, can result in significant stewardship and support for the protection or restoration of ocean ecosystems (Ainsworth et al. 2019; Beatley 2014). These links can lead to reinforcing feedbacks that perpetuate desirable or undesirable outcomes. For example, where communities or individuals are unable to meet their basic physiological needs, such as safe, nutritious food, their capacity to engage with higher-level needs such as environmental stewardship is undermined (Maslow 1943). As a result, loss of access to seafood due to ocean degradation may lead to a reduction in stewardship behaviour that leads to further environmental damage.

To address pressing sustainability issues at the intersection of ocean and society, there is a need to promote desirable and minimise undesirable interactions and feedbacks. However, intensifying and diversifying global anthropogenic developments make this a considerable challenge. Firstly human population growth increases society's pressure on the oceans, for example through rising demand for seafood (Blanchard et al. 2017) and industrialisation of the ocean (Golden et al. 2017). Secondly, large-scale anthropogenically driven environmental change impacts ocean and human health. For example, via adverse impacts on marine productivity (Singh et al. 2019), the increased prevalence of non-communicable diseases such as malnutrition (both under nutrition, e.g. stunting, and poor nutrition, e.g. obesity), and communicable disease such as cholera, (Jutla et al. 2017; Swinburn et al. 2019). Thirdly, there are major geographic inequalities in health outcomes. For example, seafood is a disproportionately a more important protein and micronutrient source in many low-income countries compared to wealthier nations (Golden et al. 2016; Hicks et al. 2019). However, it is also anticipated these same low-income countries will suffer disproportionally from climate change impacts such as the geographic redistribution of their primary seafood resources (Cheung et al. 2010; Lotze et al. 2019; Pecl et al. 2017) and rising sea-levels (Dolan and Walker 2006; Mergler et al. 2007). There are also geographic disparities in ocean health: climate-induced marine species range expansions and extinctions will likely have a greater impact on tropical regions, while invasive species will alter marine communities in polar and Southern seas (Cheung et al. 2009; Pecl et al. 2017). Countries derive different levels of benefit from marine resource extraction, with associated consequences for ocean health. For example, nations that have oil and gas reserves and exploit these resources receive significant revenues. However, they also place disproportionately more environmental pressure on associated marine ecosystem and contribute more to climate change than countries with lesser or no oil and gas reserves (Nixon 2011).

Exploring potential pathways towards a future that supports both ocean and human health is critical to improve society's capacity to achieve the Sustainable Development Goals (SDGs). In this paper, we identify 
two scenarios for 2030. The first is Business-as-Usual (BAU), which we title 'Command \& (Out of) Control ', and which focuses on the anticipated future based on our current trajectory. This BAU scenario assumes a lack of understanding of current or prospective desirable and undesirable feedbacks between ocean and human health has the potential to lead to detrimental decision-making ('Command'). The result is an 'out of control' trajectory of undesirable human and ocean health connections. The second is a more sustainable scenario, which we call 'Living \&3 Connecting', which emphasises the development of desirable interactions between ocean and human health in line with meeting the SDGs. We then explore a potential pathway to achieve the 'Living \& Connecting' scenario, highlighting key actions to move towards this future. There are two aspects to the future scenarios that should be noted here. Firstly, the futures described below are representative of the authors worldviews and experiences predominately within western cultures, and as such are primarily representative of futures in these contexts. In doing so, we note that these scenarios would differ based on different perspectives (in particular, those from the global south), and thus the interpretation of the pathways presented should be considered within this context. Secondly, in the process of writing these scenarios the COVID-19 pandemic presented the world with new challenges and imposed some major changes to economies and socioecological systems. The business as usual scenario assumes a return to the trajectory underway at the time immediately before COVID-19. We note that current disruptions to the global ocean, environment and society because of COVID-19 may indeed present a platform for change and an opportunity to 'reset' trajectories in the coming decade (as discussed in Pecl et al. in prep.).The sustainable future presented here is one option for such a shift.

\section{Business-as-Usual 2030 - 'Command ES (Out of) Control'}

Under this scenario, looking back from 2030 we can see that GDP has continued along an upward trend, though the disparities in growth within and among countries persist. The blue economy, in particular, is booming, having doubled in value to $\$ 3$ trillion since 2020 . Traditional sectors such as fisheries, shipping, and resource extraction contributed to this growth, but industries that have emerged in recent decades, such as geoengineering, offshore aquaculture, renewable energy and the mining of deep-water, previously unexplored mineral resources continue to add increasing value to the sector (Wan et al. 2018).

An increasing trend in seafood consumption continues to support the health of a burgeoning middle class globally. International coastal tourism continues to expand, along with associated service industries providing revenue and alternate livelihoods for destination communities (Fatanti and Suyadnya 2015; Kim et al. 2017; Liu et al. 2018). Health and wellbeing improve for the select demographic who can afford to take part in these tourism and recreational opportunities and incorporate more seafood into their diet. The result of these trends is that SDG 8 (Decent Work \& Economic Growth) and 9 (Industry, Innovation \& Infrastructure) were met in many countries. Furthermore, overall poverty has continued to decline (World Bank 2019), and although Sub-Saharan Africa has not attained the growth of other regions, many nations in other regions of the world meet SDG 1 (No Poverty) ahead of the 2030 target (Sachs et al. 2018).

Examples of local and regional policies and consequent management strategies that account for the inextricable links between oceans and humans, such as the Marine Framework Strategy Directive, Integrated Maritime Policy and the Marine Spatial Planning Directive within the EU are now well established (Costa and Caldeira 2018). These frameworks recognise the positive impacts that global oceans have on human health and wellbeing (McMeel et al. 2019), for example, Article 1.2 of the Marine Framework Strategy Directive "prevent and reduce inputs in the marine environment, with a view to phasing out pollution as defined in Article 3(8), so as to ensure that there are no significant impacts on or risks to marine biodiversity, marine ecosystems, human health or legitimate uses of the sea." (European Commission 2008). This progress and an increased understanding of the links between land, coastal and ocean uses regulated by these policies, has led to positive outcomes for both ocean health and human health. Unfortunately, instances of well-resourced, large-scale, integrated management are not yet widespread, and decision-making around the blue economy, human health and the marine environment are often siloed (Alexander and Haward 2019; Hoegh-Guldberg et 
al. 2019; Stephenson et al. 2019). As a result, environmental degradation has continued virtually unabated leading to few targets of SDGs 13 (Climate Action), 14 (Life Below Water) or 15 (Life on Land) being met by 2030 .

Continued negative trends in environmental conditions, together with rising inequality and vulnerability to food insecurity and disease, contribute to worsening health outcomes for populations with lower socioeconomic status (Pickett and Wilkinson 2015; Raworth 2012). Deleterious interactions between ocean and human health that have occurred more frequently since 2020 include, for example, the increasing intensity of natural disasters such as hurricanes (Knutson et al. 2013), which in addition to their direct impacts (e.g. destruction of coastal infrastructure) also negatively impact individual mental and psychological well-being by precipitating anxiety, depression, grief and trauma (Doherty and Clayton 2011). Natural disasters also have a significant impact on shipping, disrupt supply chains, affect food security, and impede access to medicines and other resources on which human health relies (Manners-Bell 2017; McDonald 2018).

Changes in the composition and functioning of estuarine and nearshore ecosystems due to coastal development and climate change, are contributing to long-term declines in coastal marine fisheries (Halpern et al. 2008; Lotze et al. 2019; Vitousek et al. 1997). The prevalence of harmful algal blooms and heavy metals is increasingly affecting the safety of seafood consumption (Cottrell et al. 2019; Fuentes-Gandara et al. 2018; Purcell et al. 2007; Sellner and Rensel 2018; Zhang and Gui 2015). These impacts are significantly reducing gains towards reaching SDG 2 (Zero Hunger). Furthermore, uneven distribution of access to resources, and unequal power among nations and between social classes is exacerbating inequality (SDG 10). Inequality is not only experienced in terms of income and livelihoods; the development of ocean literacy, mental health and stewardship are also negatively affected. For example, a loss of access to marine environments, due to the privatisation of coastlines, physically and emotionally disconnects some people from the oceans (Bennett et al. 2015; Bennett et al. 2018b). These events are leading to poor health outcomes (SDG 3) and in turn are exacerbating environmental degradation (SDG 14 and 15)(Kite-Powell et al. 2008; Pittman et al. 2019; White et al. 2016).

\section{More Sustainable 2030 - 'Living $\&$ Connecting'}

In this scenario, efforts have been made to assess human progress and well-being on a number of dimensions using well-being indicators that complement GDP (e.g. Au and Karacaoglu 2018). As such, human welfare and wellbeing have increased in most places since the start of the UN Decade of Ocean Science, while environmental degradation has slowed.

Local communities are progressively showing increased engagement, and building more sustainable relationships, with the marine environment (Foley and Kistemann 2015; White et al. 2016). Greater participation in activities including marine citizen science and community forums is enhancing individual and communitylevel environmental literacy (Kelly et al. in press). Engagement is also facilitated in novel ways through the arts. Visual and performing arts play a major role in creating awareness but importantly, benefiting mental and physical human health (e.g. Dirksen 2019; Trihanondo and Endriawan 2019). There is also enhanced knowledge exchange among scientists, community members, policy-makers and marine resource managers (Fernández Otero et al. 2019; Forrester et al. 2017; Kelly et al. 2019; Smith et al. 2019). Furthermore, 'attachment' to the oceans arising from engagement activities is reducing environmentally-damaging behaviour among people (van Putten et al. 2018b; Walker and Moscardo 2016). Engagement and the associated increase in literacy is driving a renewed eagerness to support environmental initiatives and positively impacts outcomes of SDG 13 (Climate Action), 14 (Life Below Water) and 15 (Life on Land) (Dean et al. 2019). These changes are having the additional benefit of fostering a greater sense of community (Ainsworth et al. 2019), helping to reduce social challenges such as loneliness and improving mental health outcomes (SDG 3), particularly in western nations (Downward et al. 2017; Rayon-Viña et al. 2019; Wyles et al. 2016).

Slowing environmental degradation is reliant, in part, on the speed and deliberate actions by which we are 
moving towards a circular economy. The circular economy is key to ocean health because circular process in manufacturing and industrial processes reduce extraction of resources and negative impacts on the marine environment, particularly around eco-engineering, renewable energy and offshore aquaculture (Box 2; Ellen MacArthur Foundation 2019; Falk et al. 2019). A healthy ocean is supported through strong transdisciplinary research and development teams who lead a structured and careful expansion of industry into offshore areas. These careful expansion are facilitated through for instance, the production of multi-use platforms which provide renewable energy, aquaculture, marine bio-resources and biotechnologies, maritime transport and related services, in the same marine space (Marine South East Ltd 2018; Novaglio et al. in review). These changes in ocean health have knock-on benefits for human health via a number of avenues, from improved food safety to aesthetic benefits of a healthy marine environment. Furthermore, participation in the development of circular industry practices and the use of resultant products may help individuals to internalise the value and importance of ocean health, and have it contribute to their own self-identity. This, in turn, has the potential to shape attitudes and behaviours consistent with ocean protection and enhancement.

Positive interactions between ocean and human health have strengthened since 2020; emerging innovations are reducing pollutants entering the oceans, minimising food waste, and have increased access to basic human needs such as adequate nutrition and energy (Circulate Capital LLC 2019; Willett et al. 2019; World Economic Forum 2017). There has also been an increase in the consumption of nutritionally rich seafood by previously food-insecure populations (Farmery et al. in review), reducing levels of micronutrient deficiencies and associated health conditions such as stunting and wasting (Hicks et al. 2019; Ruel et al. 2018). The result of these trends is widespread attainment of a range of SDGs e.g. SDG 1 (No Poverty), SDG 2 (Zero Hunger) and SDG 9 (Industry, Innovation \& Infrastructure).

Sustainable expansion of the blue economy is facilitated by integrated management across sectors. In the integrated management approach, the focus is a 'One Health' framework, which explicitly on both human and ocean health, and takes account of the feedbacks between them (Stephenson et al. 2019; Wilcox et al. 2019). For example, an online platform to facilitate sharing of information on harmful algal blooms among both environmental and public health agencies (Centre for Disease Control's One Health Harmful Algal Bloom System - https://www.cdc.gov/habs/ohhabs.html).

An enduring connection between human and ocean health is also ensured by a strong commitment to precautionary approaches to development and explicit consideration of social, economic and environmental trade-offs in natural resource use decision-making (Singh et al. 2017). Furthermore, standardized environmental impact assessments provide more information, which allows for integrated decision-making and cumulative impact assessment across sectors. For example, careful design and placement of new industrial developments (e.g. multi-trophic aquaculture and offshore industries) limits environmental impacts and reduces transportation costs, while maximising the positive influence of these developments on human health and well-being (SDG 3 ). As a result, there have been significant gains made towards meeting goals and targets focused primarily on the biosphere e.g. SDG 13 (Climate Action), 14 (Life Below Water) and 15 (Life on Land), which were, prior to 2021, showing little progress and were of low priority for many decision-makers (Cutter et al. 2014; GSS 2017).

In this scenario, environmental change still disproportionately affects people of low socio-economic status (Pickett and Wilkinson 2015; Raworth 2012), and inequality remains unacceptably high. However, increases in inequality have slowed since 2020 and have declined appreciably in some locations (SDG 10). The harmful interactions between ocean and human health that have strengthened since 2020 are largely of natural origin (but linked to climate change). For example, the increasing intensity of natural disasters such as hurricanes (Knutson et al. 2013) has a significant impact on human mental and physical health in affected regions. These events disrupt supply chains, affect food security, shipping, psychological safety and access to medicines and other resources on which human health has become dependent (Manners-Bell 2017; McDonald 2018). However, the increasing intensity of natural disasters and volatility in world markets for food and pharmaceutical products is being met by a greater focus on building resilience within communities, particularly among the disadvantaged and food insecure (BlueHealth 2019; Moreno et al. 2019; Sadri et al. 2018). Thus, 
these communities have an improved capacity to cope with adverse events while addressing concomitant human health issues, positively impacting attainment of SDG 3 (Good Health \& Well-being) and SDG 11 (Sustainable Cities \& Communities) (e.g. Vogel et al. 2016).

\section{Exploring the drivers that influence these alternate futures}

Here we have described two different futures for 2030 with respect to the interactions between human and ocean health, informed by our collective worldviews, perspectives and experiences. These futures are based on 5 key drivers of change that will influence where we end up at the close of the UN Decade of Ocean Science.

\section{Worldview, decision-making context, and approach to behaviour change}

The first driver of change incorporates three aspects that influence whether people can, and will, change their individual behaviours. Ourworld view (1) relates to how people perceive the world and value their own health and that of the oceans. Our world view and values directly shape attitudes which guide our individual decision-making and behaviours, and are crucial in determining future outcomes (Goldberg et al. 2018). The context in which decisions are made (2) will indirectly influence behaviour change and determine future outcomes. For example, within a policy context, political agendas, politics and public support (among other things) influence the outcomes. At a practical level, the types of policies and initiatives put in place (3) are also driven by politics, and they will influence how behaviour change is guided to achieve the desired outcomes. All three factors are important as they affect individual and collective behaviours and influence how feedbacks between ocean and society manifest (Klöckner 2013).

In the 'Living \& Connecting' scenario, the strong feedbacks between human health and environmental health are universally understood. For example, the close links between biodiversity loss, poverty and health is clear (UNEP 2015; UNEP 2019). In addition, there is a stronger focus on the development and implementation of health and environmental initiatives that target behaviour change at the community level. These schemes build community cohesion and social capital, for example, through engagement in beach clean-ups and citizen science projects. The result is policy design, development and implementation that is focused on encouraging community behaviour change that incentivises ocean stewardship, builds community resilience, and focuses on changing social norms to support pro-environmental behaviours (Cinner 2018; Faulkner et al. 2018).

In contrast, in the 'Command \& (Out of) Control' scenario, although the interactions between human and ocean health are well recognised in environmental, health, and sustainability disciplines, public understanding of these interactions remains limited. Furthermore, policy focusing on health and environmental issues employ a mixture of approaches and are implemented at different scales. For example, in some areas there is a focus on behaviour change initiatives that target the community. However, such efforts are still not well co-ordinated or linked, leading to piecemeal and inconsistent implementation (Bravo et al. 2009; Nelms et al. 2017) which undermine the potential for meaningful gains in this domain. In other areas, individuals are the focus of behaviour change initiatives. These latter approaches are based on behaviour change theories (e.g. the theory of planned behaviour) that place responsibility for change at the level of the individual as opposed to the collective, and assume personal self-efficacy can change behaviours and outcomes (Nutbeam et al. 2010). However, outcomes of such individual level campaigns do not reliably result in long-term behaviour change at a population level, as it emphasises individualist rather than communal ideals, and in many instances stigmatises individuals who have not changed their behaviour leading to their marginalisation (Albarracín et al. 2005; Davis et al. 2015; Michie and Johnston 2012). Furthermore, these approaches do not develop community cohesion or build social capital, such that the resilience of communities to cope with change in the oceans may be low (Magis 2010; Wilson 2013). 


\section{Power and Agency}

The second driver that we consider impacting future ocean and human health outcomes focusses on the capacity to create change and the capability to enact change. These apply at an individual and collective level, and can influence policy at the local, national, regional and international scale. We focus specifically on two dimensions; power and agency. Agency refers to the means and ways in which individuals can act (relying upon themselves only), or collective agency (when groups of people act for their collective selves). Powerrefers to the ways in which an individual or group of individuals can act to influence others (Haugaard 2012). Power and agency are important as they determine who can drive change, and consequently influences whether negative or positive human and ocean health outcomes emerge.

In 'Living \& Connecting', the decentralisation of power in governance enables community level behaviour change initiatives (Cvitanovic et al. 2017). Community level initiatives increase community and social capital and provide individuals with the capacity and tools to affect environmental change and shape their own health outcomes (Ko et al. 2018). For example, marine planning and development employs strategies to empower stakeholders, and discussions are facilitated for communities to collectively debate their futures (Clarke and Flannery 2019). Simultaneously, decentralisation of power may redistribute power away from private corporations to other groups in the community.

Industry increasingly supports the view that poor social and environmental management poses a significant business risk, which incentivises environmental stewardship (Franks et al. 2014; Olson 2009). These instances create a positive feedback loop, further empowering individuals and communities (Cvitanovic and Hobday 2018). For Indigenous people and communities, agency is supported by improved negotiating power with parties involved in resource use activities on (or adjacent to) the land or sea to which they are culturally connected. Favourable changes in power relations and distribution enable the transmission of Indigenous and local knowledge, and the ability of Indigenous peoples and communities to manage biodiversity (Gilberthorpe and Hilson 2016; Mustonen and Kontkanen 2019).

In 'Command \& (Out of) Control', a few global corporations influence local to global scale governance. These corporations dominate markets, and exercise significant control over developments in science and technology as well as political agendas (Blasiak et al. 2018; Folke et al. 2019). This unbalanced power situation negatively impacts the equitable distribution of resources and opportunities, with unfavourable ecological impacts and human health outcomes (Hanna 2019; Suarez-Villa 2012). The increasing use of Social Licence to Operate (SLO) is an indication that trust in (and legitimacy of) the formal regulation of natural resource management continues to erode (van Putten et al. 2018a). Even though trust in the formal regulatory system may be eroded, there are instances (typically at local scales) where communities successfully influence government and industry decision-making processes and affect industry actions (Harvey and Bice 2014; van Putten et al. 2018a).

In 'Command \& (Out of) Control', large inequities in the capacity to manage ocean and human health emerge among nations (Ottersen et al. 2014), due to imbalances in agency and power. Small island nations and low-income countries have very little economic or political power and are unable to redirect the impacts of pollution and climate change to the (often wealthier) nations who are predominantly responsible (Akpan and Bassey 2017). Similarly, low-income nations and disadvantaged communities lose access to marine resources due to the international expansion of the 'Blue Economy' (Cohen et al. 2019). For example, industry demands for access and use of Indigenous land or sea (or areas important to Indigenous people) for resource extraction, commodity production, mining, transport, and energy infrastructure can seriously challenge the rights, health and wellbeing of Indigenous peoples (Bozigar et al. 2016; Parlee 2015; Trigger et al. 2014). Dispossession and disempowerment impacts traditional management, the transmission of Indigenous and local knowledge, and the ability of Indigenous peoples and communities to manage biodiversity (Gilberthorpe and Hilson 2016), with negative outcomes for both ocean and human health at the local and global level. 


\section{Human development and industry}

Economic development, and industrial and urbanisation patterns and trends comprise this third driver of human and ocean health interactions. Human and industry development influences people's access to basic needs such as employment, energy and health care, which in turn mediate their interactions with the ocean.

In 'Living \& Connecting', significant efforts are made to assess human progress and well-being on a number of different and contextually relevant dimensions that do not replace, but instead complement, GDP growth data (e.g. Au and Karacaoglu 2018). Reporting on multiple indicators and dimensions of growth creates a positive feedback loop, because it forces decision-makers to develop and implement policy initiatives that take account of and integrate a broader suite of interrelated considerations. This de-emphasises the focus on GDP growth and re-focusses on accounting for non-renewable resource depletion, irreversible biodiversity losses, and intergenerational equity. In combination with shifts in the drivers described in previous sections, innovation and provision of a range of marine resources such as marine-derived medicines and energy, support a circular economy and a transparent approach to manufacturing and service provision.

In 'Command \& (Out of) Control', assessment of progress is largely limited to existing trajectories of GDP (Raworth 2017) and the focus is to optimise processes and revenues. This leads to disproportionate benefits for large private corporations and the wealthy, but reduces the resilience of the industry and communities to future change (Cox 2016; Gibbs 2009), with likely negative environmental and human health impacts. For example, through the loss of jobs and livelihoods and subsequent negative impacts on mental well-being.

\section{Food system}

The fourth driver that we consider impacting human and ocean health is directly related to terrestrial, aquaculture, and wild fisheries food production systems, and associated supply chains. The structure of food production systems affects all dimensions of food security (production, availability, stability and utilisation) and directly impacts human health (e.g. micronutrient deficiencies, malnutrition, obesity and chronic disease and inequalities in health status disproportionately affecting the poor). Ocean resource use and extraction directly affects the health and resilience of marine environments. Critically, because there are pervasive links between food production on land and at sea, this driver is not just focused on marine-based food systems but encompasses all food systems, crossing the land-sea boundary (Cottrell et al. 2018; Halpern et al. 2019). A further inhibitor towards achieving a sustainable relationship between human and ocean health in the BAU scenario is that when populations are systematically disadvantaged and can't meet their basic physiological needs including food, their capacity to engage with higher-level needs such as environmental stewardship is undermined. Consistent with the hierarchy of motivation proposed by Maslow (1943), in this scenario it is hard to enact behaviours to mitigate long-term risks to food supply chains and ocean health (behaviours incorporated in the self-actualisation step of the hierarchy), if in the short-term there is not enough food on a day-to-day basis, or if the only affordable food is that which compromises sustainability goals (behaviours associated with meeting basic physiological needs).

In 'Living \& Connecting', there is a shift to nutritionally-sensitive food policy and explicit recognition of the trade-offs and synergies between environmental and nutritional objectives (Farmery et al. in review; Hicks et al. 2019). For example, management interventions such as multi-use marine protected areas are being designed and implemented to successfully achieve both conservation and equitable food outcomes (Aswani and Furusawa 2007). There are concerted efforts to disseminate the lessons learnt from successful marine policy and management (e.g. Cinner et al. 2016; Cvitanovic and Hobday 2018). Decision-makers globally benefit from evidence-based information and more support for management decisions from society at large. Moves towards a circular economy are also positively influencing the sustainability of the global food system, for example, via reduced food wastage (Parfitt et al. 2010) and redirection of waste back into food production (Mo et al. 2018).

In 'Command \& (Out of) Control', the emphasis remains on increasing production in individual sectors, with considerably less focus on integrated management across sectors and 'circular' management within the food 
system. Sectoral management without integration creates conflicts between different sectors vying for ocean space and increases the prevalence of unanticipated shocks in the food system. Volatility in food availability in certain regions has significant negative consequences for moderately to severely food insecure parts of the world (Cottrell et al. 2019; FAO 2019).

\section{Lifestyle and connectedness to the oceans}

The fifth driver of change in human and ocean health is people's personal and cultural connection to the oceans. Connections to the ocean can occur, for example, via tourism, recreation, or an individual's sense of place (van Putten et al. 2018b). It is critical to consider connections to the ocean because they impact all dimensions of human health (Beute and de Kort 2014; Biedenweg et al. 2017; Frumkin et al. 2017; Marselle et al. 2019). Human connections to the ocean also impact individual and collective environmental stewardship behaviours (Chambers et al. 2019). Stewardship actions emerge as a result of the diversity of worldviews, beliefs and values that individuals and communities hold in relation to the ocean (Masterson et al. 2019).

In 'Living \& Connecting', actions and activities that build a sense of connection to the oceans are strongly valued by society. Furthermore, environmental stewardship behaviour is viewed as an integral component of a healthy individual (Moewaka Barnes and McCreanor 2019). For example, there is an increase in social prescribing (non-medical interventions and services designed to improve health behaviour) of 'blue activities' focused on exercise and conservation initiatives in aquatic environments, leading to improved health and connection to oceans across a range of demographics (Britton et al. 2018; Gibbons et al. 2017). Similarly, the role of visual and performing arts to create a connection is widely recognised and supported by government and the community (Fryer 2017). These diverse activities help individuals develop a sense of awe regarding the natural world, leading to an increase in prosocial behaviour and collective action to support ocean stewardship (Piff et al. 2015). This connection, combined with a widespread understanding of the feedbacks between ocean health and human health, drives a positive feedback loop (Figure 2).

In 'Command \& (Out of) Control', people are less connected to the ocean. People are inhibited from creating or maintaining connections because access to the oceans may be limited through existing governance arrangements (Bennett et al. 2018a), such as privatisation of coastlines (Skladany et al. 2007) or designation of marine protected areas (Mascia et al. 2010). Importantly, the lack of connection to the oceans has significant implications for how society views the ocean as a driver of human health (Masterson et al. 2019): society places more importance on optimising the quantity and/or quality of resources gained from marine systems rather than exhibiting stewardship behaviour towards the oceans (Folke et al. 2011; Holling and Meffe 1996). Their interactions with the marine environment are often resource intensive. For example, there is a rise in high-end (but environmentally insensitive) tourism that caters to a burgeoning middle class, and that does not engender a connection to the ocean. The COVID-19 experience may add additional (yet unknown) challenges for a tourism industry that will need to completely rebuild.

\section{Action pathway to move towards 'Living \& Connecting'}

Significant and transformational change will be needed to move the five drivers that mediate the interactions between human and ocean health away from the Business-as-Usual, 'Command \& (Out of) Control' trajectory towards the more sustainable world of 'Living \& Connecting'. We propose three foundations of change (bold text ) which are fundamental precursors to achieving sustainable changes at the individual, community, and policy level. The first foundation concerns marine citizenship, defined as "the rights and responsibilities of an individual towards the marine environment" (p. 839 McKinley and Fletcher 2012). Marine citizenship arises from marine education, a sense of personal responsibility for the health of the marine environment, and a feeling of connection to the oceans (McKinley and Fletcher 2010). A core principle of this foundation to change is engagement for capacity building (Ika and Donnelly 2017; Selin et al. 2016). Building of capacity will be required across scales for the second foundation of change: a more equitable distribution of power. 
A more equitable distribution of power will mean that the capacity to act (and the feeling of empowerment) is likely to be present in a greater proportion of the population (Sinharoy and Caruso 2019). With a more equitable distribution of power people will tend to participate more in decision making processes, and in a more meaningful way (Boyd 2002; Lockwood 2010; Tonelli et al. 2018), with the resultant positive impacts at both the individual and societal level encouraging ongoing participation in this way. Finally, the third foundation: greater and more equitable access to resources and opportunities, will contribute to a greater sense of agency among currently disadvantaged individuals and communities. Equitable access to resources goes hand in hand with the equitable distribution of power. Both power and resource distribution must be guided by strong foundations in the governance approach to provide certainty and build trust (Lockwood 2010; Ratner et al. 2013).

We identified 80 actions (Extended Data 1) that are critical to ensure these three foundations of change are achieved, and subsequently built upon by individual, community, and policy initiatives that move us towards our desirable 'Living \& Connecting' scenario. To gain oversight and bring clarity to the types of actions we have identified, we categorise them into different groups, called 'strategies'. These strategies should be implemented successively over the UN Decade of Ocean Science (2021-2030). Some of the actions within each strategy can be implemented immediately (in the short-term) while others may require some lead time or are dependent on other actions to precede them to take effect. In some cases, 'investment' in an action has a longer-term pay-off time (i.e. the money invested now will not return a positive benefit for some time), whereas others have immediate perceivable impacts and returns. More generally, an adaptive and reflexive approach should be taken when implementing the actions as some feedback (i.e. synergies) and timing issues are likely to arise. To gain insight into the actions (across time and also in relation to the actors who will be responsible for undertaking the actions) we provide a summary below (see Extended Data 1 for a full list of actions).

\section{Short- to mid-term strategies}

We suggest two strategies that should be implemented in the short- to mid-term that broadly relate to building knowledge, capacity and a sense of responsibility, that will help underpin marine citizenship (first half of the UN Decade of Ocean Science; Figure 3). First, 'science and health communication' should be up scaled and improved through a broad range of education and awareness-raising programs. These programs could range from, for example, formal training initiatives focused on improving ocean literacy among different stakeholder groups through to targeted public health programs (Box 3 Case Study 1). Improving ocean literacy should also include scientists and managers who are currently involved in the ocean sciences and be extended particularly to include non-traditional methods of engagements such as the visual and performing arts. The 2020 global COVID-19 experience may provide some initial insight into how alternative ways of communicating and interacting could be harnessed (in the absence of physical exposure). A greater focus on human health in marine science would seem pertinent in making the necessary transformations required to improve environmental health, and can be particularly mobilising in individualistic cultures prior to the widespread development of social capital. Irrespective of the approach used, for science and health communication to be improved to the extent required for achieving the desired pathway it is critical to move beyond simple knowledge-deficit models as is largely the case at present. Instead, science and health communication should focus on better understanding the values, beliefs and worldviews held among society so as to develop more salient, and thus effective, communication campaigns that can elicit necessary behavioural responses.

The second strategy involves what is commonly referred to as 'knowledge exchange', which focuses on the two-way exchange of knowledge among different stakeholders (Cvitanovic et al. 2015) (Box 3 Case Study 2). Underpinning knowledge exchange efforts are strong relationships and networks among key stakeholders founded upon mutual trust and respect, which enhances the flow of information, and increases the likelihood that it will be beneficially incorporated into decision-making processes (either at the individual or collective level) (Cvitanovic et al. 2016). When done successfully, knowledge exchange is linked to social learning and 
capacity development across individual and organisational levels, both of which underpin transformational change in pursuit of desired outcomes (Cvitanovic et al. 2018).

Actions falling under the 'science and health communication' and 'knowledge exchange' strategies make up $57 \%$ ( $44 \%$ and $13 \%$ respectively) of the total number of actions we propose. This is not necessarily an indication of the relative importance of marine stewardship to guide us towards the 'Living \& Connecting' scenario but is perhaps an indication that there are many different actions that can be implemented almost immediately (or at least in the medium term) related to communication and knowledge exchange. It does, however, highlight the central role and importance of knowledge for optimal ocean and human health outcomes.

\section{Longer-term strategies}

In the second half of the UN Decade of Ocean Science, we propose a greater focus on two strategies that we collectively called 'incentives' and 'rules and regulations'. These two strategies directly guide individual, community and business behaviours that impact ocean and human health; for example, through modification of industry practices. Successful implementation of the large number of actions aimed at building marine citizenship in the first half of the UN Decade of Ocean Science, will be necessary to prepare us for implementing the next set of actions focused on guiding behaviours in a more structured way.

Some lead time may be needed to achieve behaviour change of resource users, whether individuals or industry, especially if there are regulatory changes or actions that need to filter through other systems like the consumer market. To enable behaviour change, both a 'stick' and 'carrot' approach are likely to be needed (Box 3). Examples of carrots are economic incentives which have a clear role alongside regulations (sticks). Incentives can be provided by government, such as tax incentives to provide food to the domestic rather than the export market, or NGO-driven, such as promoting low 'food miles' as a way of guiding food choice. Similarly, incentives could be entirely driven by industry and the demand and preferences of their consumers, such as extending product shelf life to increase the accessibility and safety of products. Regulations can affect the behaviour of resource users very directly through economic, social and fiscal policy and a variety of other rules. For instance, stronger regulation around recycling, reuse and reduction of waste are an important example on how we can aim towards 'Living \& Connecting'. Many possible actions were identified for 'Incentives' (23\% of all actions identified) and 'Rules and regulations' (21\%) (Extended Data 1).

It is worth noting that actions implemented under the 'rules \& regulations' strategy may fail to achieve intrinsic attitudinal and behavioural change which is required for long-term positive change if they were undertaken in isolation (Cohen et al. 1994). This is why positive reinforcement (incentives) where people are more likely to internalise the motivation are required in parallel. Moreover, the early to midterm 'science and health communication' and 'knowledge exchange' strategies will also help build intrinsic motivation which leads to sustained engagement in desired behaviours beyond the provision of initial incentives (Bardi and Schwartz 2003).

\section{By whom and for whom}

The agencies or actors responsible for implementing the actions under each of the strategies will differ. In some cases, it is government who need to drive and implement the action (e.g. education programs, regulations and taxes, and economic incentives), whereas for other actions it is industry, NGOs or the community who need to take responsibility. However, in most instances, a combination of agencies and actors will need to share responsibility for particular actions, with government playing an especially important role in enabling the implementation of actions. These combinations are also likely to differ depending on the scale of the action, or the specific context in which it is situated. 
Furthermore, it should be noted, that while we provide descriptions of concrete actions to affect change and move towards 'Living \& Connecting' by 2030 (Extended Data Table 1), these actions require different combinations of capital (e.g. natural, social or economic). As a result they are likely to require modifications to tailor them to particular contexts, such as for developing nations or countries under non-democratic political systems (Sachs et al. 2019). The benefits of the actions are unlikely to be distributed equitably if the local context is not adequately considered. The risk of failure of the actions to have the desired effect or perhaps even have some unknown and unintended consequences is acknowledged. Some of the risk categories can be identified and some are more obvious than others, such as a lack of capacity and resources. However, other less obvious but real risks also apply such as a lack of commitment, lack of influence/impact, or technically impossible action. If these risks are identified early, it will reduce the potential for unsuccessful implementation or adverse unintended consequences.

\section{The journey to an inclusive UN Decade of Ocean Science}

The futures and action pathway developed here were drawn from a western scientific and cultural view of the world. To ensure the UN Decade of Ocean Science "provide[s] a 'once in a lifetime' opportunity for nations to work together to generate the global ocean science needed to support the sustainable development of our shared ocean" (p.2, IOC 2019), it is essential to increase the breadth of voices included in the creation of any vision of a sustainable future. An important gap that needs to be forged is acknowledging and integrating the perspectives and knowledge systems of Indigenous and Traditional Knowledge Holders. Traditional knowledge holders have the potential to provide invaluable and often overlooked perspectives on the feedbacks between ocean and human health due to their intimate cultural ties to land and sea, enriching any narrative of the future. For example:

"Traditional Tasmanian Aboriginal shell necklace practices are under a direct and measurable climate threat which is not only an ecological and cultural disaster but one that at the very least affects Aboriginal people in mental health and economic terms and at worst in some extreme cases destroys their ability to connect to 'Sea/ Marine country." Dean Greeno, Palawa Man

In this quote Dean demonstrates the strong link between ocean health (that is threatened for instance by climate impacts) and the physical connection, family interactions, and mental wellbeing (through the activity or necklace making) of Australian Aboriginal people. As a result, we present our paper as just the start of a discussion - a jumping off point for bringing together the diversity of views necessary to envision a sustainable and equitable future.

\section{Conclusions}

After carefully considering the main drivers that shape our ocean and human health interactions (worldviews, power and agency, human development and industry, food systems, and lifestyle and connectedness) it is clear that, using current knowledge, we can shape the next decade to either end up in a 'Command \& (Out of) Control' or 'Living \& Connecting' future. The latter of these should be our aspiration but achieving it will require immediate action that is maintained throughout the UN Decade of Ocean Science.

Even though in a 'Command \& (Out of) Control' future (which is our current trajectory if we continue along our Business-as-Usual approach) we will attain some SDGs, these are far fewer than if we aim for the more sustainable 'Living \& Connecting'. Notably SDGs 13 (Climate Action), 14 (Life Below Water) or 15 (Life on Land) are unlikely to be met by 2030 if Business-as-Usual prevails. We also contend that health outcomes (SDG 3) are unlikely to be met in a 'Command \& (Out of) Control' future. If we choose to aim for the more sustainable 'Living \& Connecting' (and we suggest we should), we are likely to get better outcomes for SDG 1 (No Poverty), SDG 2 (Zero Hunger) and SDG 9 (Industry, Innovation \& Infrastructure) as well as SDGs 13 (Climate Action), 14 (Life Below Water) and 15 (Life on Land). 
To steer us in the direction of 'Living \& Connecting', we need to focus on creating marine citizenship, achieving a more equitable distribution of power, and greater and more equitable access to resources and opportunities. In the short and medium term, we can start with creating marine citizenship by implementing actions that improve science and health communication initiatives and knowledge exchange strategies. This provides a solid foundation for additional medium to longer term actions, that require more lead time. These medium to long term actions are aimed at guiding targeted behaviour change in individuals, communities and business through incentives, and rules and regulations. Government has an important role to play in enabling actions both in the short and long term, however, industry, NGOs and the community at large also need to take responsibility, and in many instances a concerted effort is required by all parties working collaboratively. While in some cases this would represent a fundamental shift in our approach to achieving the SDGs (e.g. through new and improved partnerships between science agencies and large private global corporations), and thus also require large scale institutional reform to adequately facilitate such changes, doing so will be critical for achieving improved outcomes for both ocean and human health.

\section{Methods}

We used an iterative process to develop the alternate futures for our Grand Challenge. For full details of the methods please see Nash et al. (in review). Here, we provide methods specific to our challenge. We identified 70 drivers, which were initially grouped into 12 umbrella drivers (Extended Data 1). To select drivers for incorporation into the alternate futures narratives, all authors were asked to evaluate each umbrella driver with respect to importance to the challenge and potential for society to influence the behaviour of the umbrella driver. A discussion of the results of this exercise highlighted that only those umbrella drivers that were directly linked to both human and ocean health had been selected as important with respect to the impact of the umbrella driver on the challenge. For example, 'innovations in human health' was considered to have a moderate to important impact on human health but was not perceived to have an important impact on ocean health. As a result, this umbrella driver only had a low to moderately important impact on the challenge overall. This result revealed a potential weakness of this step in the process, as it didn't explicitly account for the indirect interactions arising from feedbacks between human and ocean health. As a consequence, we refined the umbrella drivers to an updated list of 5 umbrella drivers (in the main text, just termed 'drivers') for use in developing the alternate futures: (1) Worldview, decision-making context and approach to behaviour change; (2) Power and agency; (3) Human development and industry; (4) Food system; and (5) Lifestyle and connectedness to the oceans. We explored the potential trajectories of these drivers from Business-as-Usual to pathways that were more in line with the SDGs. Using published research relevant to each driver, we identified a series of descriptors of the drivers under the two 2030 scenarios (Table S1), based on likely and possible trajectories for the drivers. It should be noted that these drivers are not mutually exclusive, and overlap in many ways, as shown in the section on 'Exploring the drivers that influence these alternate futures'.

\section{Acknowledgements}

Funding for Future Seas was provided by the Centre for Marine Socioecology, IMAS, MENZIES and the College of Arts, Law and Education, and the College of Science and Engineering at UTAS. We acknowledge support from a Research Enhancement Program grant from the DVCR Office at UTAS. We are grateful to Dean Greeno and Sutej Hugu for their perspectives on indigenous connections to Sea/Marine Country. We acknowledge and pay respect to the traditional owners and custodians of sea country all around the world and recognise their collective wisdom and knowledge of our oceans and coasts. 


\section{References}

Ainsworth GB, Kenter JO, O'Connor S, Daunt F, Young JC (2019) A fulfilled human life: eliciting sense of place and cultural identity in two UK marine environments through the Community Voice Method. Ecosys Serv 39:100992 doi:https://doi.org/10.1016/j.ecoser.2019.100992

Akpan DA, Bassey I (2017) Economic diplomacy, global waste trade: the african perspective since the 20th century. African Journal of History and Archaeology 2:1-10

Albarracín D, Gillette JC, Earl AN, Glasman LR, Durantini MR, Ho M-H (2005) A test of major assumptions about behavior change: a comprehensive look at the effects of passive and active HIV-prevention interventions since the beginning of the epidemic. Psychological bulletin 131:856-897 doi:10.1037/0033-2909.131.6.856

Alexander KA, Haward M (2019) The human side of marine ecosystem-based management (EBM): 'Sectoral interplay' as a challenge to implementing EBM. Mar Pol 101:33-38 doi:https://doi.org/10.1016/j.marpol.2018.12.019

Arkema KK et al. (2013) Coastal habitats shield people and property from sea-level rise and storms. Nat Clim Change 3:913-918 doi:10.1038/nclimate1944

Aswani S, Furusawa T (2007) Do marine protected areas affect human nutrition and health? a comparison between villages in Roviana, Solomon islands. Coast Manag, 35:545-565 doi:10.1080/08920750701593394

Au J, Karacaoglu G (2018) Beyond GDP: measuring New Zealand's wellbeing progress. State of the State New Zealand. New Zealand. https://www2.deloitte.com/content/dam/Deloitte/nz/Documents/publicsector/Deloitte-NZ-SotS-2018-Article-2.pdf.

Bardi A, Schwartz SH (2003) Values and behavior: strength and structure of relations. Personality and Social Psychology Bulletin 29:1207-1220 doi:10.1177/0146167203254602

Beatley T (2014) Blue urbanism: exploring connections between cities and oceans. Island Press,

Bennett NJ, Govan H, Satterfield T (2015) Ocean grabbing. Mar Pol 57:61-68 doi:https://doi.org/10.1016/j.marpol.2015.03.026

Bennett NJ et al. (2018a) Coastal and Indigenous community access to marine resources and the ocean: a policy imperative for Canada. Mar Pol 87:186-193 doi:https://doi.org/10.1016/j.marpol.2017.10.023

Bennett NJ, Whitty TS, Finkbeiner E, Pittman J, Bassett H, Gelcich S, Allison EH (2018b) Environmental stewardship: a conceptual review and analytical framework. Environmental Management 61:597-614 doi:10.1007/s00267-017-0993-2

Beute F, de Kort YAW (2014) Salutogenic effects of the environment: review of health protective effects of nature and daylight. Applied Psychology: Health and Well-Being 6:67-95 doi:10.1111/aphw.12019

Biedenweg K, Scott RP, Scott TA (2017) How does engaging with nature relate to life satisfaction? demonstrating the link between environment-specific social experiences and life satisfaction. Journal of Environmental Psychology 50:112-124 doi:https://doi.org/10.1016/j.jenvp.2017.02.002

Birney L, McNamara D (2018) Advanced placement environmental science and the Curriculum and Community Enterprise for Restoration Science (CCERS) project in the New York City high school. Journal of Curriculum and Teaching 7:7-12

Blanchard JL et al. (2017) Linked sustainability challenges and trade-offs among fisheries, aquaculture and agriculture. Nat Ecol Evol 1:1240-1249 doi:10.1038/s41559-017-0258-8

Blasiak R, Jouffray J-B, Wabnitz CCC, Sundström E, Österblom H (2018) Corporate control and global governance of marine genetic resources. Science Advances 4:eaar5237 doi:10.1126/sciadv.aar5237

BlueHealth (2019) BlueHealth 2020: linking environment, climate and health. Accessed 7/11/2019 
Boyd E (2002) The Noel Kempff project in Bolivia: gender, power, and decision-making in climate mitigation. Gender \& Development 10:70-77 doi:10.1080/13552070215905

Bozigar M, Gray CL, Bilsborrow RE (2016) Oil extraction and indigenous livelihoods in the northern Ecuadorian amazon. World Development 78:125-135 doi:https://doi.org/10.1016/j.worlddev.2015.10.035

Bravo M, de los Ángeles Gallardo M, Luna-Jorquera G, Núñez P, Vásquez N, Thiel M (2009) Anthropogenic debris on beaches in the SE Pacific (Chile): results from a national survey supported by volunteers. Mar Pollut Bull 58:1718-1726 doi:https://doi.org/10.1016/j.marpolbul.2009.06.017

Britton E, Kindermann G, Domegan C, Carlin C (2018) Blue care: a systematic review of blue space interventions for health and wellbeing. Health Promotion International 35:50-69 doi:10.1093/heapro/day103

Caref E, Lawrence S (2018) If you give a kid an oyster: reflections on collaborations in placebased STEM education through oyster restoration science in new york city. Journal of STEM outreach 1:24-34

Chambers R et al. (2019) The Marine CoLAB: Taking a CoLABorative, values based approach to connect people to the ocean. Frontiers Mar Sci 6 doi:10.3389/fmars.2019.00619

Chapman BK, McPhee D (2016) Global shark attack hotspots: Identifying underlying factors behind increased unprovoked shark bite incidence. Ocean Coast Manag 133:72-84 doi:https://doi.org/10.1016/j.ocecoaman.2016.09.010

Cheung WWL, Lam VWY, Sarmiento JL, Kearney K, Watson R, Pauly D (2009) Projecting global marine biodiversity impacts under climate change scenarios. Fish Fish 10:235-251 doi:10.1111/j.14672979.2008.00315.x

Cheung WWL, Lam VWY, Sarmiento JL, Kearney K, Watson REG, Zeller D, Pauly D (2010) Large-scale redistribution of maximum fisheries catch potential in the global ocean under climate change. Glob Change Biol 16:24-35 doi:10.1111/j.1365-2486.2009.01995.x

Chin A, Kyne PM, Walker TI, McAuley RB (2010) An integrated risk assessment for climate change: analysing the vulnerability of sharks and rays on Australia's Great Barrier Reef. Glob Change Biol 16:19361953 doi:10.1111/j.1365-2486.2009.02128.x

Cinner JE (2018) How behavioral science can help conservation. Science 362:889 doi:10.1126/science.aau6028

Cinner JE et al. (2016) Bright spots among the world's coral reefs. Nature 535:416-419 doi:10.1038/nature18607

Circulate Capital LLC (2019) The incubator network. Accessed 31/05/2019

Clarke J, Flannery W (2019) The post-political nature of marine spatial planning and modalities for its re-politicisation. J Environ Pol Plan:1-14 doi:10.1080/1523908X.2019.1680276

Cohen PJ et al. (2019) Securing a Just Space for Small-Scale Fisheries in the Blue Economy. Frontiers in Marine Science 6 doi:10.3389/fmars.2019.00171

Cohen SL, Pedersen J, Kinney GG, Myers J (1994) Effects of reinforcement history on responding under progressive-ratio schedules of reinforcement. J Exp Anal Behav 61:375-387 doi:10.1901/jeab.1994.61-375

Costa S, Caldeira R (2018) Bibliometric analysis of ocean literacy: an underrated term in the scientific literature. Mar Pol 87:149-157 doi:https://doi.org/10.1016/j.marpol.2017.10.022

Cottrell RS, Fleming A, Fulton EA, Nash KL, Watson RA, Blanchard JL (2018) Considering land-sea interactions and trade-offs for food and biodiversity. Glob Chang Biol 24:580-596 doi:10.1111/gcb.13873

Cottrell RS et al. (2019) Food production shocks across land and sea. Nat Sustain doi:10.1038/s41893-018$0210-1$ 
Cox M (2016) The pathology of command and control: a formal synthesis. Ecol Soc 21 doi:10.5751/ES-08698210333

Cutter A, Sconfienza U, Ullah F (2014) Tests of success for the SDGs: a tool for designing and assessing Sustainable Development Goals and targets. https://www.sustainabledevelopment2015.org/index.php/news/284-news-sdgs/1543-tests-of-success-forthe-sdgs-tool.

Cvitanovic C, Hobday AJ (2018) Building optimism at the environmental science-policy-practice interface through the study of bright spots. Nat Comms 9:3466 doi:10.1038/s41467-018-05977-w

Cvitanovic C, Hobday AJ, McDonald J, Van Putten EI, Nash KL (2017) Governing fisheries through the critical decade: the role and utility of polycentric systems. Rev Fish Biol Fisheries doi:10.1007/s11160-0179495-9

Cvitanovic C, Hobday AJ, van Kerkhoff L, Wilson SK, Dobbs K, Marshall NA (2015) Improving knowledge exchange among scientists and decision-makers to facilitate the adaptive governance of marine resources: A review of knowledge and research needs. Ocean Coast Manag 112:25-35 doi:http://dx.doi.org/10.1016/j.ocecoaman.2015.05.002

Cvitanovic C, Löf MF, Norström AV, Reed MS (2018) Building university-based boundary organisations that facilitate impacts on environmental policy and practice. PLOS ONE 13:e0203752 doi:10.1371/journal.pone.0203752

Cvitanovic C, McDonald J, Hobday AJ (2016) From science to action: principles for undertaking environmental research that enables knowledge exchange and evidence-based decision-making. Journal of Environmental Management 183:864-874 doi:https://doi.org/10.1016/j.jenvman.2016.09.038

Davis R, Campbell R, Hildon Z, Hobbs L, Michie S (2015) Theories of behaviour and behaviour change across the social and behavioural sciences: a scoping review. Health psychology review 9:323-344 doi:10.1080/17437199.2014.941722

Dean AJ, Barnett AG, Wilson KA, Turrell G (2019) Beyond the 'extinction of experience' - novel pathways between nature experience and support for nature conservation. Glob Environ Change 55:48-57 doi:https://doi.org/10.1016/j.gloenvcha.2019.02.002

Dirksen R (2019) Haiti's drums and trees: facing loss of the sacred. Ethnomusicology 63:43-77 doi:10.5406/ethnomusicology.63.1.0043

Doherty TJ, Clayton S (2011) The psychological impacts of global climate change. American Psychologist 66:265-276 doi:10.1037/a0023141

Dolan AH, Walker IJ (2006) Understanding vulnerability of coastal communities to climate change related risks. Journal of Coastal Research:1316-1323

Downward P, Hallmann K, Rasciute S (2017) Exploring the interrelationship between sport, health and social outcomes in the UK: implications for health policy. European Journal of Public Health 28:99-104 doi:10.1093/eurpub/ckx063

Ellen MacArthur Foundation (2019) Cities and circular economy for food.

European Commission (2008) Directive 2008/56/EC of the European Parliament and of the Council of 17 June 2008 establishing a framework for community action in the field of marine environmental policy (Marine Strategy Framework Directive). Official Journal of the European Union 164:19-40

Falk J et al. (2019) Exponential roadmap 1.5. Sweden.

FAO (2019) The state of food security and nutrition in the world. FAO, Rome, Italy. 
Farmery A et al. (in review) Food for all: designing sustainable and secure future seafood systems. Future Seas Project. Rev Fish Biol Fisheries.

Fatanti MN, Suyadnya IW (2015) Beyond user gaze: how instagram creates tourism destination brand? Procedia - Social and Behavioral Sciences 211:1089-1095 doi:https://doi.org/10.1016/j.sbspro.2015.11.145

Faulkner L, Brown K, Quinn T (2018) Analyzing community resilience as an emergent property of dynamic social-ecological systems. Ecol Soc 23 doi:10.5751/ES-09784-230124

Fernández Otero RM, Bayliss-Brown GA, Papathanassiou M (2019) Ocean literacy and knowledge transfer synergies in support of a sustainable blue economy. Frontiers Mar Sci 6 doi:10.3389/fmars.2019.00646

Fleming LE, Maycock B, White MP, Depledge MH (2019) Fostering human health through ocean sustainability in the 21st century. People \& Nat 0 doi:10.1002/pan3.10038

Foley R, Kistemann T (2015) Blue space geographies: enabling health in place. Health \& Place 35:157-165 doi:https://doi.org/10.1016/j.healthplace.2015.07.003

Folke C et al. (2011) Reconnecting to the biosphere. Ambio 40:719-738 doi:10.1007/s13280-011-0184-y

Folke C et al. (2019) Transnational corporations and the challenge of biosphere stewardship. Nat Ecol Evol doi:10.1038/s41559-019-0978-z

Forrester TD, Baker M, Costello R, Kays R, Parsons AW, McShea WJ (2017) Creating advocates for mammal conservation through citizen science. Biol Conserv 208:98-105 doi:https://doi.org/10.1016/j.biocon.2016.06.025

Franks DM, Davis R, Bebbington AJ, Ali SH, Kemp D, Scurrah M (2014) Conflict translates environmental and social risk into business costs. Proc National Acad Sci 111:7576 doi:10.1073/pnas.1405135111

Frumkin H et al. (2017) Nature contact and human health: a research agenda. Environmental Health Perspectives 125:075001 doi:10.1289/EHP1663

Fryer JL (2017) Art-based placemaking at Renfrew Ravine: Implications for sustainable places. Simon Fraser University

Fuentes-Gandara F, Pinedo-Hernández J, Marrugo-Negrete J, Díez S (2018) Human health impacts of exposure to metals through extreme consumption of fish from the Colombian Caribbean Sea. Environmental Geochemistry and Health 40:229-242 doi:10.1007/s10653-016-9896-z

Garrett JK, Clitherow TJ, White MP, Wheeler BW, Fleming LE (2019) Coastal proximity and mental health among urban adults in England: the moderating effect of household income. Health \& Place:102200 doi:https://doi.org/10.1016/j.healthplace.2019.102200

Gibbons A, Hardman M, Howarth M, James C, Sherriff G (2017) Care farming and green care in Salford. University of Salford

Gibbs L, Warren A (2015) Transforming shark hazard policy: learning from ocean-users and shark encounter in Western Australia. Mar Pol 58:116-124 doi:https://doi.org/10.1016/j.marpol.2015.04.014

Gibbs MT (2009) Resilience: what is it and what does it mean for marine policymakers? Mar Pol 33:322-331 doi:https://doi.org/10.1016/j.marpol.2008.08.001

Gilberthorpe E, Hilson G (2016) Natural resource extraction and indigenous livelihoods: development challenges in an era of globalization. Routledge,

Goldberg JA, Marshall NA, Birtles A, Case P, Curnock MI, Gurney GG (2018) On the relationship between attitudes and environmental behaviors of key Great Barrier Reef user groups. Ecol Soc 23 doi:10.5751/ES$10048-230219$ 
Golden CD et al. (2016) Nutrition: fall in fish catch threatens human health. Nature 534:317-320 doi:10.1038/534317a

Golden JS, Virdin J, Nowacek D, Halpin P, Bennear L, Patil PG (2017) Making sure the blue economy is green. Nat Ecol Evol 1:0017 doi:10.1038/s41559-016-0017

GSS (2017) Evaluating progress towards the Sustainable Development Goals. https://sustainability.com/ourwork/reports/evaluating-progress-towards-sustainable-development-goals/.

Halpern BS et al. (2019) Opinion: Putting all foods on the same table: Achieving sustainable food systems requires full accounting. Proc National Acad Sci 116:18152 doi:10.1073/pnas.1913308116

Halpern BS et al. (2017) Drivers and implications of change in global ocean health over the past five years. PLOS ONE 12:e0178267 doi:10.1371/journal.pone.0178267

Halpern BS et al. (2008) A global map of human impact on marine ecosystems. Science 319:948-952 doi:10.1126/science.1149345

Hanna TM (2019) Reclaiming democratic control: The role of public ownership in resisting corporate domination. 2019 25:7 doi:10.5195/jwsr.2019.901

Harvey B, Bice S (2014) Social impact assessment, social development programmes and social licence to operate: tensions and contradictions in intent and practice in the extractive sector. Impact Assessment and Project Appraisal 32:327-335 doi:10.1080/14615517.2014.950123

Haugaard M (2012) Rethinking the four dimensions of power: domination and empowerment. Journal of Political Power 5:33-54 doi:10.1080/2158379X.2012.660810

Heithaus MR, Wirsing AJ, Dill LM (2012) The ecological importance of intact top-predator populations: a synthesis of 15 years of research in a seagrass ecosystem. Mar Freshw Rev 63:1039-1050

Hicks CC et al. (2019) Harnessing global fisheries to tackle micronutrient deficiencies. Nature 574:95-98 doi:10.1038/s41586-019-1592-6

Hoegh-Guldberg O, Northrop E, Lubchenco J (2019) The ocean is key to achieving climate and societal goals. Science 365:1372-1374 doi:10.1126/science.aaz4390

Holling CS, Meffe GK (1996) Command and control and the pathology of natural resource management. Conserv Biol 10:328-337 doi:10.1046/j.1523-1739.1996.10020328.x

Ika LA, Donnelly J (2017) Success conditions for international development capacity building projects. International Journal of Project Management 35:44-63 doi:https://doi.org/10.1016/j.ijproman.2016.10.005

IOC (2019) The science we need for the ocean we want: The United Nations Decade of Ocean Science for Sustainable Development (2021-2030). vol IOC Brochure 2018-7 (IOC/BRO/2018/7 Rev). Paris, France

Janis S, Birney L, Newton R (2016) Billion oyster project: linking public school teaching and learning to ecological restoration of New York Harbor using innovative applications of environmental and digital technologies. International journal of digital content technology and its applications 10

Jutla A, Khan R, Colwell R (2017) Natural disasters and cholera outbreaks: current understanding and future outlook. Current Environmental Health Reports 4:99-107 doi:10.1007/s40572-017-0132-5

Kelly $\mathrm{R}$ et al. (in press) Connecting to the oceans: supporting ocean literacy and public engagement. Rev Fish Biol Fisheries.

Kelly R, Fleming A, Pecl GT, Richter A, Bonn A (2019) Social license through citizen science: a tool for marine conservation. Ecol Soc 24 doi:10.5751/ES-10704-240116

Kim JY, Chung N, Ahn KM (2017) The impact of mobile tour information services on destination travel intention. Information Development 35:107-120 doi:10.1177/0266666917730437 
Kite-Powell HL et al. (2008) Linking the oceans to public health: current efforts and future directions. Environmental Health 7:S6 doi:10.1186/1476-069X-7-S2-S6

Klöckner CA (2013) A comprehensive model of the psychology of environmental behaviour-A meta-analysis. Glob Environ Change 23:1028-1038 doi:https://doi.org/10.1016/j.gloenvcha.2013.05.014

Knutson TR et al. (2013) Dynamical downscaling projections of twenty-first-century atlantic hurricane activity: CMIP3 and CMIP5 model-based scenarios. Journal of Climate 26:6591-6617 doi:10.1175/JCLI-D-1200539.1

Ko H, Kim H, Yoon C-g, Kim C-y (2018) Social capital as a key determinant of willingness to join community-based health insurance: a household survey in Nepal. Public Health 160:52-61 doi:https://doi.org/10.1016/j.puhe.2018.03.033

Liu H, Wu L, Li X (2018) Social media envy: how experience sharing on social networking sites drives millennials' aspirational tourism consumption. Journal of Travel Research 58:355-369 doi:10.1177/0047287518761615

Lockwood M (2010) Good governance for terrestrial protected areas: a framework, principles and performance outcomes. Journal of Environmental Management 91:754-766 doi:https://doi.org/10.1016/j.jenvman.2009.10.005

Lotze HK et al. (2019) Global ensemble projections reveal trophic amplification of ocean biomass declines with climate change. Proc National Acad Sci:201900194 doi:10.1073/pnas.1900194116

Magis K (2010) Community resilience: an indicator of social sustainability. Soc Nat Resour 23:401-416 doi:10.1080/08941920903305674

Malve H (2016) Exploring the ocean for new drug developments: marine pharmacology. J Pharm Bioallied Sci 8:83-91 doi:10.4103/0975-7406.171700

Manners-Bell J (2017) Supply chain risk management: understanding emerging threats to global supply chains. Kogan Page Publishers,

Marine South East Ltd (2018) Multi-use offshore platforms: creating infrastructure for ocean sustainability. https://www.offshoreplatforms.eu/.

Marselle RM, Warber LS, Irvine NK (2019) Growing resilience through interaction with nature: can group walks in nature buffer the effects of stressful life events on mental health? International Journal of Environmental Research and Public Health 16 doi:10.3390/ijerph16060986

Mascia MB, Claus CA, Naidoo R (2010) Impacts of marine protected areas on fishing communities. Conserv Biol 24:1424-1429 doi:10.1111/j.1523-1739.2010.01523.x

Maslow AH (1943) A theory of human motivation. Psychological Review 50:370-396 doi:10.1037/h0054346

Masterson VA, Enqvist JP, Stedman RC, Tengö M (2019) Sense of place in social-ecological systems: from theory to empirics. Sustain Sci 14:555-564 doi:10.1007/s11625-019-00695-8

McCagh C, Sneddon J, Blache D (2015) Killing sharks: the media's role in public and political response to fatal human-shark interactions. Mar Pol 62:271-278 doi:https://doi.org/10.1016/j.marpol.2015.09.016

McDonald C (2018) The rising tide of maritime shipping risks. Risk Management 65:4-7

McKinley E, Fletcher S (2010) Individual responsibility for the oceans? An evaluation of marine citizenship by UK marine practitioners. Ocean Coast Manag 53:379-384 doi:https://doi.org/10.1016/j.ocecoaman.2010.04.012

McKinley E, Fletcher S (2012) Improving marine environmental health through marine citizenship: a call for debate. Mar Pol 36:839-843 doi:https://doi.org/10.1016/j.marpol.2011.11.001 
McMeel O, Tonné N, Calewaert J-B (2019) Human health and EU maritime policy: Closing the loop. H2020 SOPHIE Project. Brussels, Belgium.

Mergler D, Anderson HA, Chan LHM, Mahaffey KR, Murray M, Sakamoto M, Stern AH (2007) Methylmercury exposure and health effects in humans: a worldwide concern. AMBIO: A Journal of the Human Environment 36:3-12

Merkens J-L, Reimann L, Hinkel J, Vafeidis AT (2016) Gridded population projections for the coastal zone under the Shared Socioeconomic Pathways. Global and Planetary Change 145:57-66 doi:https://doi.org/10.1016/j.gloplacha.2016.08.009

Michie S, Johnston M (2012) Theories and techniques of behaviour change: developing a cumulative science of behaviour change. Health Psychology Review 6:1-6 doi:10.1080/17437199.2012.654964

Ministry of Health (2017) Māori health models - Te Whare Tapa Whā. https://www.health.govt.nz/ourwork/populations/maori-health/maori-health-models/maori-health-models-te-whare-tapa-wha.

Mo WY, Man YB, Wong MH (2018) Use of food waste, fish waste and food processing waste for China's aquaculture industry: needs and challenge. Sci Total Environ 613-614:635-643 doi:https://doi.org/10.1016/j.scitotenv.2017.08.321

Moewaka Barnes H, McCreanor T (2019) Colonisation, hauora and whenua in Aotearoa. Journal of the Royal Society of New Zealand 49:19-33 doi:10.1080/03036758.2019.1668439

Moreno J, Lara A, Torres M (2019) Community resilience in response to the 2010 tsunami in Chile: the survival of a small-scale fishing community. International Journal of Disaster Risk Reduction 33:376-384 doi:https://doi.org/10.1016/j.ijdrr.2018.10.024

Mustonen T, Kontkanen H (2019) Safe places: increasing Finnish waterfowl resilience through human-made wetlands. Polar Science 21:75-84 doi:https://doi.org/10.1016/j.polar.2019.05.007

Nash KL, Alexander KA, Melbourne-Thomas J, Novioaglio C, Sbrocchi C, Villanueva C, Pecl GT (in review) Developing achievable alternate futures for key challenges during the UN decade of ocean science for sustainable development. Rev Fish Biol Fisheries.

Neff C (2012) Australian beach safety and the politics of shark attacks. Coast Manag, 40:88-106 doi:10.1080/08920753.2011.639867

Nelms SE, Coombes C, Foster LC, Galloway TS, Godley BJ, Lindeque PK, Witt MJ (2017) Marine anthropogenic litter on British beaches: a 10-year nationwide assessment using citizen science data. Sci Total Environ 579:1399-1409 doi:https://doi.org/10.1016/j.scitotenv.2016.11.137

Neumann B, Vafeidis AT, Zimmermann J, Nicholls RJ (2015) Future coastal population growth and exposure to sea-level rise and coastal flooding - a global assessment. PLOS ONE 10:e0118571 doi:10.1371/journal.pone.0118571

Nixon R (2011) Slow violence and the environmentalism of the poor. Harvard University Press,

Novaglio C et al. (in review) Deep aspirations: towards a sustainable offshore blue economy. Rev Fish Biol Fisheries.

Nutbeam D, Harris E, Wise W (2010) Theory in a nutshell: a practical guide to health promotion theories. McGraw-Hill,

Olson EG (2009) Business as environmental steward: the growth of greening. Journal of Business Strategy 30:4-13 doi:10.1108/02756660910987563

Ottersen OP et al. (2014) The political origins of health inequity: prospects for change. The Lancet 383:630-667 doi:10.1016/S0140-6736(13)62407-1 
Parfitt J, Barthel M, Macnaughton S (2010) Food waste within food supply chains: quantification and potential for change to 2050. Philos Trans Royal Soc B 365:3065-3081 doi:doi:10.1098/rstb.2010.0126

Parlee BL (2015) Avoiding the resource curse: indigenous communities and Canada's oil sands. World Development 74:425-436 doi:https://doi.org/10.1016/j.worlddev.2015.03.004

Pecl G et al. (in prep) Transforming our oceans for the future we want. Future Seas Project www.futureseas2030.org.

Pecl GT et al. (2017) Biodiversity redistribution under climate change: impacts on ecosystems and human well-being. Science 355:eaai9214

Pepin-Neff C, Wynter T (2018) Shark bites and shark conservation: an analysis of human attitudes following shark bite incidents in two locations in Australia. Conserv Lett 11:e12407 doi:10.1111/conl.12407

Pickett KE, Wilkinson RG (2015) Income inequality and health: a causal review. Social Science \& Medicine 128:316-326 doi:https://doi.org/10.1016/j.socscimed.2014.12.031

Piff PK, Dietze P, Feinberg M, Stancato DM, Keltner D (2015) Awe, the small self, and prosocial behavior. Journal of personality and social psychology 108:883

Pittman SJ et al. (2019) Marine parks for coastal cities: a concept for enhanced community well-being, prosperity and sustainable city living. Mar Pol 103:160-171 doi:https://doi.org/10.1016/j.marpol.2019.02.012

Purcell JE, Uye S, Lo W (2007) Anthropogenic causes of jellyfish blooms and their direct consequences for humans: a review. Mar Ecol Prog Ser 350:153-174

Ratner B, Meinzen-Dick R, May C, Haglund E (2013) Resource conflict, collective action, and resilience: an analytical framework. International Journal of the Commons 7

Raworth K (2012) A safe and just space for humanity: can we live within the doughnut? vol 8. Oxfam Policy and Practice: Climate Change and Resilience. Oxfam, Oxford. https://www.oxfam.org/sites/www.oxfam.org/files/dp-a-safe-and-just-space-for-humanity-130212-en.pdf.

Raworth K (2017) Doughnut economics. Penguin Random House, London, UK

Rayon-Viña F, Miralles L, Fernandez-Rodríguez S, Dopico E, Garcia-Vazquez E (2019) Marine litter and public involvement in beach cleaning: disentangling perception and awareness among adults and children, Bay of Biscay, Spain. Mar Pollut Bull 141:112-118 doi:https://doi.org/10.1016/j.marpolbul.2019.02.034

Ruel MT, Quisumbing AR, Balagamwala M (2018) Nutrition-sensitive agriculture: what have we learned so far? Global Food Security 17:128-153 doi:https://doi.org/10.1016/j.gfs.2018.01.002

Sachs JD, Schmidt-Traub G, Kroll C, Lafortune G, Fuller G (2018) SDG Index and Dashboards Report 2018. New York, USA. https://www.sdgindex.org/reports/2018/.

Sachs JD, Schmidt-Traub G, Mazzucato M, Messner D, Nakicenovic N, Rockström J (2019) Six transformations to achieve the Sustainable Development Goals. Nat Sustain 2:805-814 doi:10.1038/s41893-019-0352-9

Sadri AM et al. (2018) The role of social capital, personal networks, and emergency responders in postdisaster recovery and resilience: a study of rural communities in Indiana. Natural Hazards 90:1377-1406 doi:10.1007/s11069-017-3103-0

Sahajwalla V (2018) Green processes: transforming waste into valuable resources. Engineering 4:309-310 doi:https://doi.org/10.1016/j.eng.2018.05.011

Selin C et al. (2016) Experiments in engagement: designing public engagement with science and technology for capacity building. Public Understanding of Science 26:634-649 doi:10.1177/0963662515620970 
Sellner KG, Rensel JE (2018) Prevention, control, and mitigation of harmful algal bloom impacts on fish, shellfish, and human consumers. In: S. E. Shumway, Burkholder JM, Morton SL (eds) Harmful Algal Blooms. doi:10.1002/9781118994672.ch12

Seto KC (2011) Exploring the dynamics of migration to mega-delta cities in Asia and Africa: Contemporary drivers and future scenarios. Glob Environ Change 21:S94-S107 doi:https://doi.org/10.1016/j.gloenvcha.2011.08.005

Singh GG et al. (2017) A rapid assessment of co-benefits and trade-offs among Sustainable Development Goals. Mar Pol:223-231 doi:doi.org/10.1016/j.marpol.2017.05.030

Singh GG et al. (2019) Climate impacts on the ocean are making the Sustainable Development Goals a moving target travelling away from us. People \& Nat 1:317-330 doi:10.1002/pan3.26

Sinharoy SS, Caruso BA (2019) On World Water Day, gender equality and empowerment require attention. The Lancet Planetary Health 3:e202-e203 doi:10.1016/S2542-5196(19)30021-X

Skladany M, Clausen R, Belton B (2007) Offshore aquaculture: the frontier of redefining oceanic property. Soc Nat Resour 20:169-176

Smith JR, Witherington B, Heimlich JE, Lindborg RJ, Neidhardt E, Savage A (2019) Public sea turtle watches serve as effective environmental education. Environmental Education Research 25:292-308 doi:10.1080/13504622.2018.1509300

Steffen W, Broadgate W, Deutsch L, Gaffney O, Ludwig C (2015) The trajectory of the Anthropocene: the Great Acceleration. Anthr Rev 2:81-98 doi:10.1177/2053019614564785

Stephenson RL et al. (2019) A practical framework for implementing and evaluating integrated management of marine activities. Ocean Coast Manag 177:127-138 doi:https://doi.org/10.1016/j.ocecoaman.2019.04.008

Strickland J (2017) A brief look at human impacts on sharks. Journal of Aquaculture \& Marine Biology $5: 1-4$

Suarez-Villa L (2012) Globalization and technocapitalism. . Routledge, London, UK. doi:doi.org/10.4324/9781315585123

Swinburn BA et al. (2019) The global syndemic of obesity, undernutrition, and climate change: The Lancet Commission report. The Lancet 393:791-846 doi:10.1016/S0140-6736(18)32822-8

Tonelli DF, Sant'Anna L, Barcelar Abbud E, Aparecida de Souza S (2018) Antecedents, process, and equity outcomes: a study about collaborative governance. Cogent Business \& Management 5:1469381 doi: $10.1080 / 23311975.2018 .1469381$

Trigger D, Keenan J, de Rijke K, Rifkin W (2014) Aboriginal engagement and agreement-making with a rapidly developing resource industry: Coal seam gas development in Australia. The Extractive Industries and Society 1:176-188 doi:https://doi.org/10.1016/j.exis.2014.08.001

Trihanondo D, Endriawan D (2019) Cultural and environmental conservation through community service program in Girimekar village. IOP Conference Series: Earth and Environmental Science 239:012050 doi: $10.1088 / 1755-1315 / 239 / 1 / 012050$

UNEP (2015) Our planet: healthy planet, healthy people.

UNEP (2019) Global Environmental Outlook-GEO-6: Healthy Planet, Healthy People. Press CU Nairobi, van Putten IE, Cvitanovic C, Fulton E, Lacey J, Kelly R (2018a) The emergence of social licence necessitates reforms in environmental regulation. Ecol Soc 23 doi:10.5751/ES-10397-230324 
van Putten IE, Plagányi ÉE, Booth K, Cvitanovic C, Kelly R, Punt AE, Richards SA (2018b) A framework for incorporating sense of place into the management of marine systems. Ecol Soc 23 doi:10.5751/ES-10504230404

Vitousek PM et al. (1997) Human alteration of the global nitrogen cycle: sources and consequences. Ecol Appl 7:737-750 doi:10.1890/1051-0761(1997)007[0737:HAOTGN]2.0.CO;2

Vogel C, Scott D, Culwick CE, Sutherland C (2016) Environmental problem-solving in South Africa: harnessing creative imaginaries to address 'wicked' challenges and opportunities. South African Geographical Journal 98:515-530 doi:10.1080/03736245.2016.1217256

Walker K, Moscardo G (2016) Moving beyond sense of place to care of place: the role of Indigenous values and interpretation in promoting transformative change in tourists' place images and personal values. Journal of Sustainable Tourism 24:1243-1261 doi:10.1080/09669582.2016.1177064

Wan Z, el Makhloufi A, Chen Y, Tang J (2018) Decarbonizing the international shipping industry: Solutions and policy recommendations. Mar Pollut Bull 126:428-435 doi:https://doi.org/10.1016/j.marpolbul.2017.11.064

White MP, Pahl S, Wheeler BW, Fleming LEF, Depledge MH (2016) The 'Blue Gym': what can blue space do for you and what can you do for blue space? J Mar Biol Assoc UK 96:5-12 doi:10.1017/S0025315415002209

Wilcox BA, Aguirre AA, De Paula N, Siriaroonrat B, Echaubard P (2019) Operationalizing one health employing social-ecological systems theory: lessons from the greater mekong sub-region. Front Public Health 7:85-85 doi:10.3389/fpubh.2019.00085

Willett W et al. (2019) Food in the Anthropocene: the EAT-LancetCommission on healthy diets from sustainable food systems. The Lancet 393:447-492 doi:10.1016/S0140-6736(18)31788-4

Wilson GA (2013) Community resilience, policy corridors and the policy challenge. Land Use Policy 31:298310 doi:https://doi.org/10.1016/j.landusepol.2012.07.011

World Bank (2019) PovcalNet: an online analysis tool for global poverty monitoring. Accessed 04/07/2019

World Economic Forum (2017) Shaping the future of global food systems: a scenarios analysis. World Economic Forum's system initiative on shaping the future of food security and agriculture. Geneva, Switzerland. http://www3.weforum.org/docs/IP/2016/NVA/WEF_FSA_FutureofGlobalFoodSystems.pdf.

World Health Organization (1946) Preamble to the Constitution of the World Health Organization as adopted by the International Health Conference.[Official Records of the World Health Organization, no. 2, p. 100] 1948 [cited 2012 May 4]. New York, June, Geneva, Switzerland.

Wyles KJ, Pahl S, Holland M, Thompson RC (2016) Can beach cleans do more than clean-up litter? Comparing beach cleans to other coastal activities. Environment and Behavior 49:509-535 doi: $10.1177 / 0013916516649412$

Yozzo DJ, Wilber P, Will RJ (2004) Beneficial use of dredged material for habitat creation, enhancement, and restoration in New York-New Jersey Harbor. Journal of Environmental Management 73:39-52 doi:https://doi.org/10.1016/j.jenvman.2004.05.008

Zhang Q, Gui J-F (2015) Virus genomes and virus-host interactions in aquaculture animals. Science China Life Sciences 58:156-169 doi:10.1007/s11427-015-4802-y

FIGURE 1: Desirable and undesirable interactions between ocean and human health (see Box 1 for definitions). 


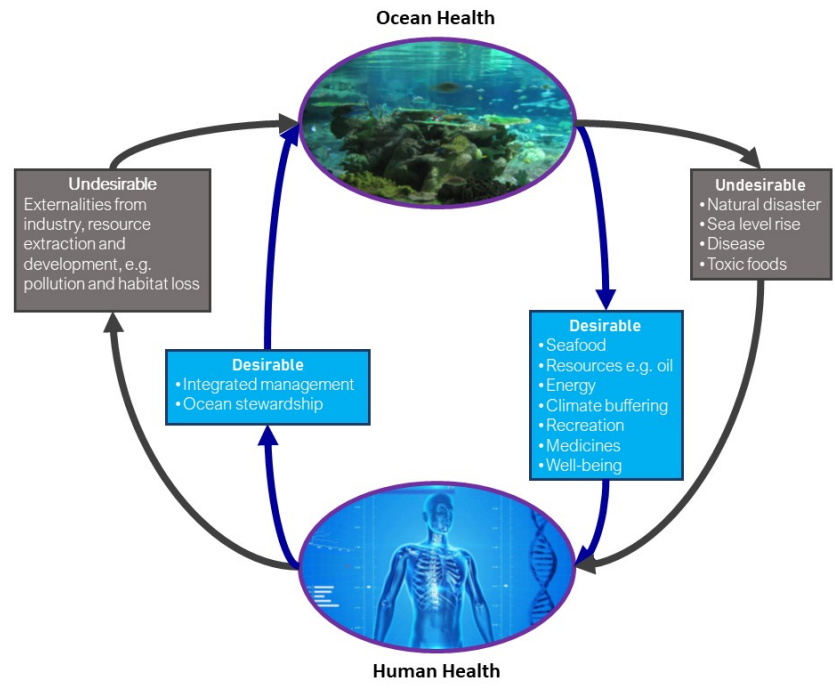

FIGURE 2: Example of the feedback loop between ocean health and human health (see Box 1 for definitions) due to interaction with the ocean and mediated by world view and ocean literacy. Human health is a prerequisite for human populations to consider and act on issues of environmental stewardship. Conversely, a healthy ocean and interaction with the ocean contributes to human health.

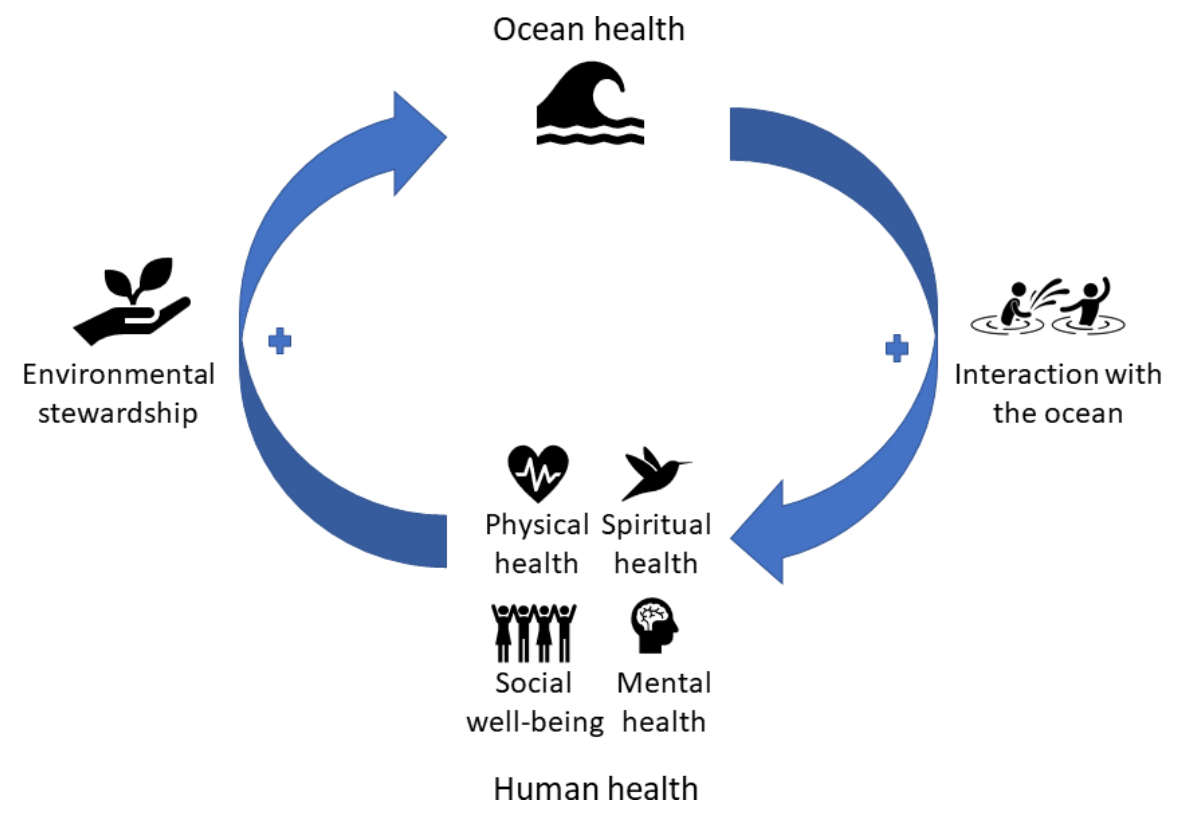

FIGURE 3: Pathway to achieving 'Living \& Connecting 2030' based on four strategies: science and health communication, knowledge exchange, incentives, and rules and regulations. These strategies are implemented in 3 stages across the UN Decade for Ocean Science. Example actions and their anticipated outcome are provided. 


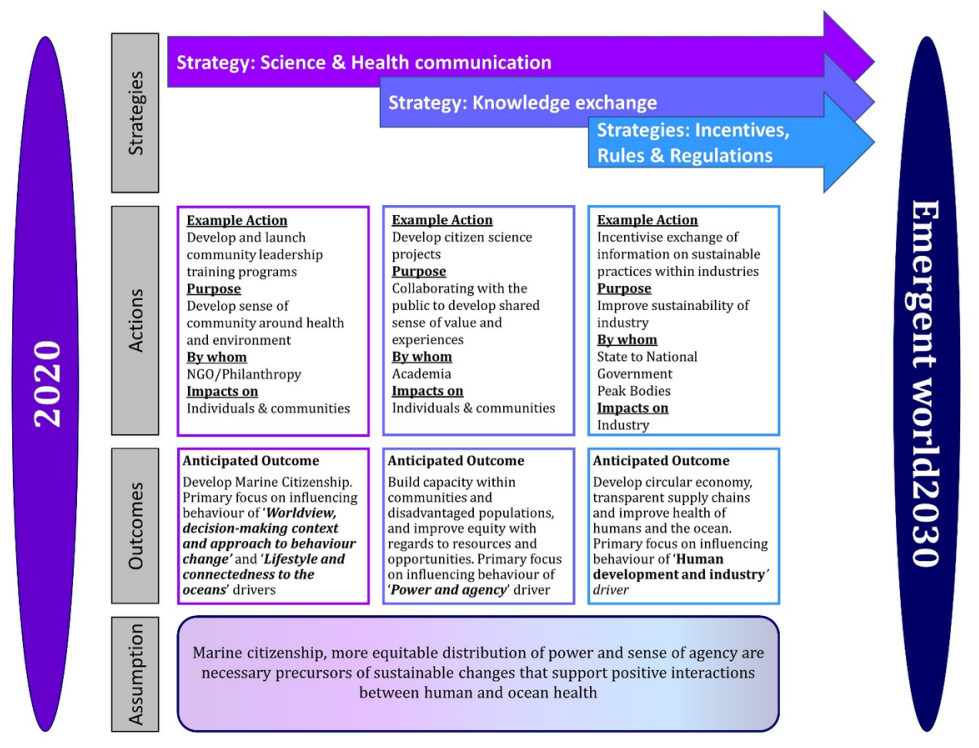

BOX 1: Definitions of human and ocean health

Human health - A broad definition of health has been assumed, based on the WHO definition of health as "a state of complete physical, mental and social well-being and not merely the absence of disease or infirmity" (World Health Organization 1946). Spiritual health is also included as this has been articulated in some Indigenous definitions of health (e.g. Te Whare Tapa Wha - Māori health Ministry of Health 2017). Equity and equitable access to health care and resources that support health is an additional critical dimension included in our definition.

Ocean health - There are multiple dimensions to ocean health. From a utilitarian perspective ocean health may be defined by the ecosystem services they provide. From a non-utilitarian perspective, ocean health may be defined as marine ecosystems where broad ecosystem structure and function is maintained. This can be in a pristine, altered, or novel ecosystem state. Our perceptions of ocean health are mediated by the values we attribute to these different ecosystem states.

BOX 2: The potential for environmental engineering to support moves towards a circular economy

New environmental technologies are emerging to address the need for reuse of resources and reduction in consumption to address SDG 12 (Sustainable Consumption \& Production). Over 1 and half billion tonnes of steel are produced each year. This process requires approximately 800 million tonnes of coal each year (Figure B2.1), with implications for climate change, negatively impacting ocean health (Singh et al. 2019) and human health (Knutson et al. 2013). 'Green Steel', provides one example of environmental engineering that is currently gaining traction. This process uses old tyres and rubbish (Figure B2.2) to replace coal in the coking process, and the use of 'flock' stripped from old cars to produce ceramics and high value carbons (Sahajwalla 2018). If manufacturing sectors embrace such technological solutions, there is potential to significant environmental gains whilst also supporting human health and development.

Figure B2.1: Antelope Coal Mine in Wyoming; B2.2: Tyres used to replace coal in steel making process. Image credits: Coal mine -"P1010319" by WildEarthGuardians and"Tyres" by JaredEarleare both licensed under $C C B Y-N C-N D$ 2.0 . 

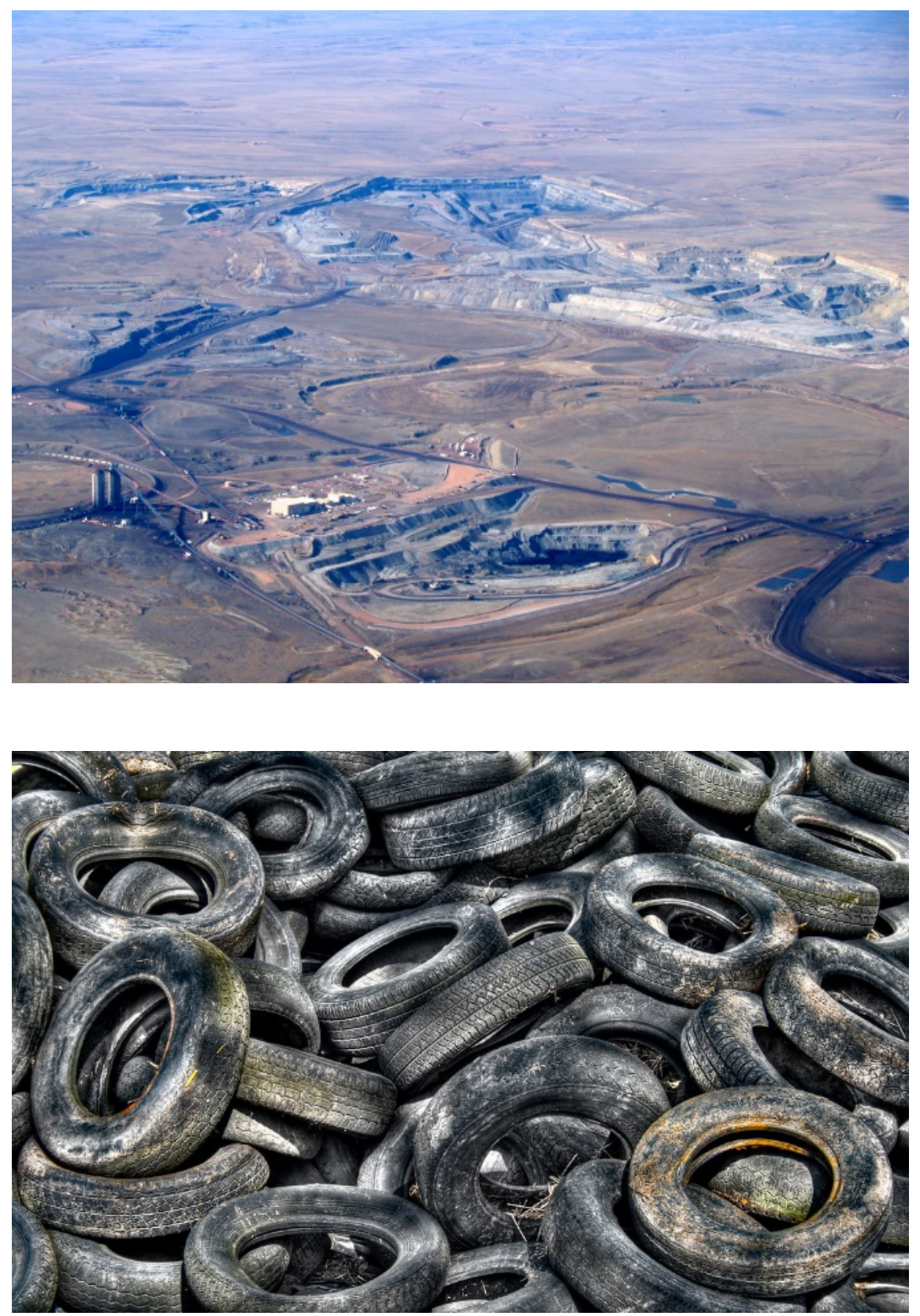

BOX 3: Examples of the four strategies identified as important to achieving a more sustainable 2030.

Case study 1: Science and health communication

At the beginning of the $20^{\text {th }}$ century, all of the oysters in New York Harbour had been eaten, reefs had been dredged or covered in silt and the water quality was extremely poor (Yozzo et al. 2004). However, by the turn of the $21^{\text {st }}$ century, environmental laws like the Clean Water Act meant improved water quality to the extent that oysters could be re-established. The Billion Oyster Project (BOP; https://billionoysterproject.org/) is a long-term initiative, run in conjunction with New York City schools, to restore one billion live oysters to the New York Harbor over a 20-year period. The premise of BOP is that secondary school students 
can and should play a direct, authentic role in restoring their local environment, and that the practice of teaching and learning is enhanced as the work and study of keystone species and habit restoration is integrated into curricula and school-based activities (Janis et al. 2016). To date, 30,000 oysters have been restored and a new Ecosystem Engineers curriculum has been developed - covering topics such as oyster anatomy, how oysters' clean water, the food web in New York Harbour and oyster reef construction (https://billionoysterproject.org/). Furthermore, the program has had significant educational benefits, including for marginalised students within the community (Birney and McNamara 2018; Caref and Lawrence 2018).

Case study 2: Knowledge exchange

In many marine ecosystems, sharks play an ecological important role as apex predators (Heithaus et al. 2012). Thus, declining shark populations due to overfishing and climate change are a significant cause for concern (Chin et al. 2010; Strickland 2017). However, sharks also present a water safety risk in many areas of the world, with the number of unprovoked shark bites, while rare, on the rise (Chapman and McPhee 2016). Shark encounters or a perceived change in the risk of encounters, for example through media coverage, can alter the way people use and enjoy the ocean for swimming and watersports (Gibbs and Warren 2015; McCagh et al. 2015) potentially impacting on human health. In regions of Australia with a relatively high number of shark encounters, state governments and local authorities have instigated shark mitigation programs (e.g. phone apps, drum lines, nets, drones, helicopter warning systems) to reduce the risk of human-shark encounters (Neff 2012). However, there is only a nascent understanding of recreational ocean user's perceptions of risk, and how they respond to mitigation measures (Pepin-Neff and Wynter 2018). In a project funded by the New South Wales State Government, knowledge exchange between researchers, managers and the coastal community (including young adults) through workshop events at surf lifesaving clubs and schools, is increasing understanding and awareness of three relevant aspects of shark encounters: i) shark behaviour, movement, and abundance, ii) the different types of mitigation methods and devices, iii) people's perceptions of risk of encounters, and iv) ocean user's behavioural responses to different shark mitigation measures. In this ongoing project, workshops are leading to a shared understanding among ocean users, authorities and scientists that there are links between having healthy shark populations and a healthy ocean, and that both were valued by all stakeholder groups. Given that healthy shark populations are valued by many members of the public (Gibbs and Warren 2015; Pepin-Neff and Wynter 2018), better understanding of people's responses to non-lethal mitigation measures is anticipated to lead to the desired levels of risk mitigation for ocean users. Healthy minds and bodies from surfing, swimming, and other recreational activities can be encouraged while non-lethal mitigation measures (combined with sustainable fisheries management) will help ensure healthy shark populations.

Case study 3: Incentives

Food Smart City (https://www.tcd.ie/tceh/projects/foodsmartdublin/), a collaborative project developed by Trinity College Dublin, is working in Ireland to encourage sustainable seafood consumption by leveraging coastal cultural heritage, such as traditional recipes, and engaging with restaurateurs, educators and ECO-UNESCO (Ireland's Environmental Education and Youth Organisation). The project is developing a framework of knowledge exchange and action that addresses the global and topical issue of sustainable food from the oceans (e.g. SDGs 2, 4, 11). A core component of the project are experiential food events around the city which are aimed at incentivising Irish people to consider consumption of local sustainable seafood. These 'casual, accessible' events engage people in fun experiences of seafood that are affordable and healthy for both people and the environment. As a result, Irish communities are being incentivised to alter consumption patterns to preference local food, produced sustainably, with positive outcomes for human nutrition and ocean health.

Case study 4: Rules \& Regulations

One of the most comprehensively documented case studies of how participatory approaches to governance can enhance fisheries sustainability comes from the Sumilon and Apo Islands in the Philippines (Alcala and 
Russ 2006). With a long history of destructive fishing practices by large commercial fishing companies, the depletion of local fish stocks and degradation of associated ecosystems were threatening the livelihoods of local communities (Russ and Alcala 1999). At the time, the management of local fisheries was under a centralized governance system that encouraged greater use (exploitation) of natural resources. That is, regulations did not limit catch, fishing effort, or the sizes of landed fish. However, acknowledgement of the shortcomings of this approach resulted in a shift towards participatory governance that devolved responsibility to local governments and local communities (Pomeroy and Carlos 1997). Alcala and Russ (2006) conclude that this institutional shift from a centralized governance system towards a more inclusive system empowered the various stakeholders, which underpinned the recovery of fish stocks, fisheries, and livelihoods in the area.

Supplementary Material for

\section{Oceans \& Society: Feedbacks between ocean and human health}

Extended Data Table 1: Full list of brainstormed drivers and their grouping within umbrella drivers.

Table S1: Descriptors of umbrella drivers used to develop the alternate futures.

Extended Data Table 2: Full list of actions identified to move towards the more sustainable future for 2030.

TABLE S1: Descriptors of umbrella drivers used to develop the alternate futures.

\begin{tabular}{|c|c|c|}
\hline Umbrella Driver & Business-as-Usual 2030 & More Sustainable 2030 \\
\hline \multirow[t]{6}{*}{$\begin{array}{l}\text { Human development \& } \\
\text { Industry }\end{array}$} & $\begin{array}{l}\text { Still very focused on growth \& } \\
\text { linear economy }\end{array}$ & $\begin{array}{l}\text { Move towards circular \& balanced } \\
\text { economy \& transparent supply } \\
\text { chains }\end{array}$ \\
\hline & GDP as measure of progress & GDP as measure of progress \\
\hline & $\begin{array}{l}\text { but isolated use of other } \\
\text { wellbeing indicators }\end{array}$ & $\begin{array}{l}\text { and natural capital included in } \\
\text { global development accounting } \\
\text { and use of other wellbeing } \\
\text { indicators becoming widespread }\end{array}$ \\
\hline & Inequality still increasing & $\begin{array}{l}\text { Inequality still unacceptably } \\
\text { high but has not increased } \\
\text { significantly since } 2020\end{array}$ \\
\hline & $\begin{array}{l}\text { Some success of green } \\
\text { technologies in certain sectors. } \\
\text { Capacity to design and } \\
\text { implement these technologies } \\
\text { isolated }\end{array}$ & $\begin{array}{l}\text { Widespread use of green } \\
\text { technologies and sharing of } \\
\text { knowledge to support this } \\
\text { widespread use }\end{array}$ \\
\hline & $\begin{array}{l}\text { Industry focused on } \\
\text { optimisation }\end{array}$ & $\begin{array}{l}\text { Industry focused on } \\
\text { optimisation and long-term } \\
\text { resilience to change }\end{array}$ \\
\hline
\end{tabular}

TABLE S1: Continued 


\begin{tabular}{|c|c|c|}
\hline $\begin{array}{l}\text { Worldview, decision-making } \\
\text { context and approach to } \\
\text { behaviour change }\end{array}$ & $\begin{array}{l}\text { Limited awareness of the links } \\
\text { between human health and ocean } \\
\text { health and this is reflected in } \\
\text { policy }\end{array}$ & $\begin{array}{l}\text { Widespread understanding of } \\
\text { feedbacks between human \& } \\
\text { ocean health and this is reflected } \\
\text { in policy }\end{array}$ \\
\hline & $\begin{array}{l}\text { Policy focus on social } \\
\text { determinants of health such as } \\
\text { level of education }\end{array}$ & $\begin{array}{l}\text { Policy focus on accessing } \\
\text { desirable feedbacks between } \\
\text { environmental health and } \\
\text { human health }\end{array}$ \\
\hline & $\begin{array}{l}\text { Under-resourcing and siloing } \\
\text { (environment/ } \\
\text { social/economic/cultural, } \\
\text { disciplinary, sectoral) of } \\
\text { management is limiting } \\
\text { effectiveness }\end{array}$ & $\begin{array}{l}\text { Integrated environmental } \\
\text { management \& strong } \\
\text { commitment to precautionary } \\
\text { approaches to development }\end{array}$ \\
\hline & $\begin{array}{l}\text { Continued reliance on } \\
\text { regulation and the markets to } \\
\text { manage behaviour (because we } \\
\text { live in a neoliberal society), } \\
\text { limited use of other more social } \\
\text { incentives e.g. changing social } \\
\text { norms, improved stakeholder } \\
\text { engagement in corporate } \\
\text { decisions }\end{array}$ & $\begin{array}{l}\text { Desirable behaviour is } \\
\text { facilitated through a more } \\
\text { balanced governance approach } \\
\text { (using regulation, markets and } \\
\text { social incentives) }\end{array}$ \\
\hline
\end{tabular}

TABLE S1: Continued

\begin{tabular}{|c|c|c|}
\hline Umbrella Driver & Business-as-Usual 2030 & More Sustainable 2030 \\
\hline \multirow[t]{4}{*}{ Power \& Agency } & $\begin{array}{l}\text { Disempowered individuals caused } \\
\text { by limited awareness of: a) the } \\
\text { links between human health and } \\
\text { ocean health; b) an individual's } \\
\text { capacity to create change; c) the } \\
\text { tools available to effect change }\end{array}$ & $\begin{array}{l}\text { Decentralisation of governance } \\
\text { power to local levels leads to } \\
\text { increasing community level } \\
\text { behaviour change initiatives }\end{array}$ \\
\hline & $\begin{array}{l}\text { Gradual/patchy/uncoordinated } \\
\text { change in emphasis from } \\
\text { individual- to community-level } \\
\text { behaviour change initiatives }\end{array}$ & $\begin{array}{l}\text { Mechanisms are in place to } \\
\text { reduce the influence of } \\
\text { corporations on government } \\
\text { (i.e. restrictions on political } \\
\text { donations) }\end{array}$ \\
\hline & $\begin{array}{l}\text { Power to influence government } \\
\text { is held by a few wealthy global } \\
\text { corporations }\end{array}$ & $\begin{array}{l}\text { Ability to negotiate is } \\
\text { proportional to distribution of } \\
\text { negative externalities rather } \\
\text { than economic power }\end{array}$ \\
\hline & $\begin{array}{l}\text { Low and middle income and } \\
\text { small island nations do not have } \\
\text { equal representation in ocean } \\
\text { and human health governance } \\
\text { but suffer the negative } \\
\text { externalities of development }\end{array}$ & $\begin{array}{l}\text { Individuals are empowered by } \\
\text { increased awareness of: a) the } \\
\text { links between human health and } \\
\text { ocean health; b) an individual's } \\
\text { capacity to create change; c) the } \\
\text { tools available to effect change }\end{array}$ \\
\hline
\end{tabular}


TABLE S1: Continued

\begin{tabular}{|c|c|c|}
\hline Food system & Focus on optimising production & $\begin{array}{l}\text { Focus on building resilience } \\
\text { within food system }\end{array}$ \\
\hline & $\begin{array}{l}\text { Awareness of the links between } \\
\text { food systems on land and sea } \\
\text { but this awareness not } \\
\text { translated into policy } \\
\text { Seafood is increasingly } \\
\text { demanded by the burgeoning } \\
\text { middle class aware of the health } \\
\text { benefits of these foods } \\
\text { Expansion of mariculture, but } \\
\text { large focus on producing luxury } \\
\text { products for high-income } \\
\text { countries } \\
\text { Highly inequitable distribution } \\
\text { of nutritious seafood products } \\
\text { Nutrition of pregnant \& } \\
\text { lactating women \& children } \\
\text { under } 5 \text { are of extreme concern } \\
\text { in certain areas } \\
\text { Nutritionally/ecologically } \\
\text { sensitive seafood production } \\
\text { practices are showing promise } \\
\text { but have not been widely } \\
\text { implemented } \\
\text { Toxic algal blooms and } \\
\text { pollution of increasing concern } \\
\text { for seafood production }\end{array}$ & $\begin{array}{l}\text { Food policy accounts for risks } \\
\text { and opportunities arising from } \\
\text { the links between food } \\
\text { production on land and sea } \\
\text { Seafood has become a widely } \\
\text { recognised key element in food } \\
\text { security and nutrition strategies } \\
\text { (individual to policy-makers) } \\
\text { Expansion of sustainable } \\
\text { mariculture to meet nutritional } \\
\text { requirements in at-risk } \\
\text { populations } \\
\text { Increasingly equitable } \\
\text { distribution of nutritious } \\
\text { seafood products } \\
\text { Reduction in maternal, foetal } \\
\text { and child mortality, and } \\
\text { childhood stunting in } \\
\text { historically deficient areas } \\
\text { Lessons learnt from successful } \\
\text { nutrition and conservation } \\
\text { policy and management being } \\
\text { used to inform and support } \\
\text { decision-makers world-wide } \\
\text { Success in scaling up green } \\
\text { engineering programs has led to } \\
\text { a reduction in marine pollution } \\
\text { in certain areas }\end{array}$ \\
\hline
\end{tabular}

TABLE S1: Continued

\begin{tabular}{lll}
\hline Umbrella Driver & Business-as-Usual 2030 & More Sustainable 2030 \\
\hline $\begin{array}{l}\text { Lifestyle \& Connectedness } \\
\text { to the oceans }\end{array}$ & $\begin{array}{l}\text { Engagement with local } \\
\text { environment and coasts patchy }\end{array}$ & $\begin{array}{l}\text { High community engagement } \\
\text { with local environment and } \\
\text { coasts leading to reduced }\end{array}$ \\
& $\begin{array}{l}\text { loneliness in some localities and } \\
\text { higher connectedness to the }\end{array}$ \\
& $\begin{array}{l}\text { oceans } \\
\text { International tourism continues }\end{array}$ \\
& to be popular but also increase \\
to increase (influencers & in local recreation, participation \\
promoting 'must-see' $\mathcal{E}$ & in citizen science opportunities \\
'last-chance' destinations) & etc) (influencers are increasing \\
& & promoting local recreation \\
& & opportunities, citizen science)
\end{tabular}




\begin{tabular}{lll}
\hline Umbrella Driver & Business-as-Usual 2030 & More Sustainable 2030 \\
\hline $\begin{array}{l}\text { Carbon offsetting a mainstream } \\
\text { behaviour but efficacy in } \\
\text { reducing emissions questioned }\end{array}$ & $\begin{array}{l}\text { Carbon offsetting schemes have } \\
\text { received considerable attention } \\
\text { and efficacy has improved } \\
\text { dramatically }\end{array}$ \\
$\begin{array}{ll}\text { Influx of tourism dollars to } \\
\text { destinations but often not } \\
\text { shared with local community, is } \\
\text { increasing living costs for locals } \\
\text { and leading to loss of access to } \\
\text { coasts due to privatisation }\end{array}$ & $\begin{array}{l}\text { Influx of tourism dollars to } \\
\text { sharing of income derived from } \\
\text { tourists }\end{array}$ \\
& \\
\hline
\end{tabular}

